\title{
Processing, Properties, and Wear Resistance of Aluminides
}

\author{
R. N. Wright \\ B. H. Rabin \\ J. K. Wright \\ Published March 1993
Idaho National Engineering Laboratory
EG\&G Idaho, Inc.
Idaho Falls, Idaho 83415

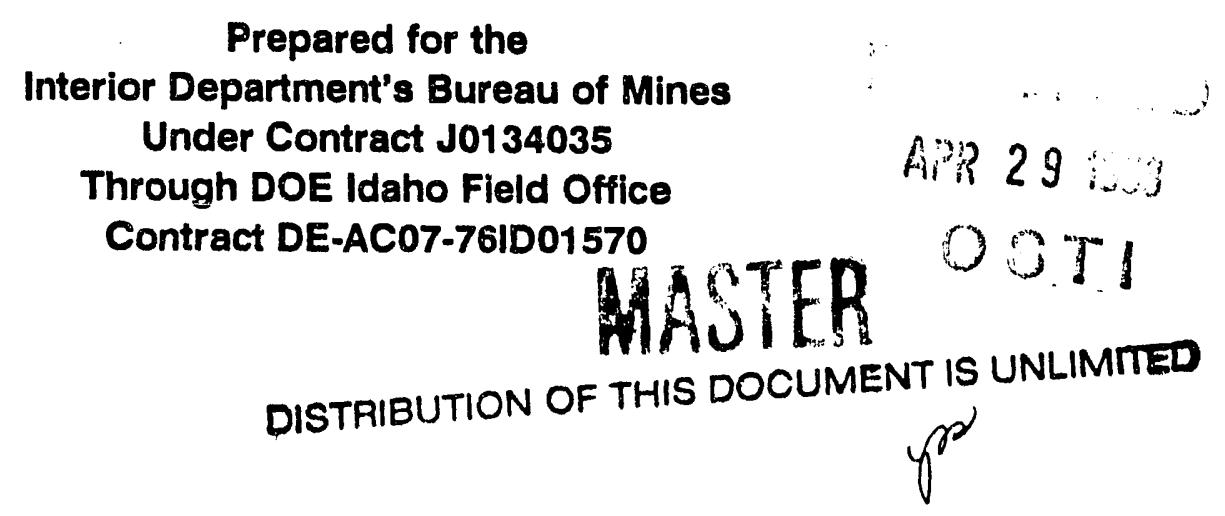




\section{ABSTRACT}

The resistance of alloys based on $\mathrm{Fe}_{3} \mathrm{Al}$ to abrasive wear and cavitation erosion has been characterized. These alloys exhibit excellent resistance to both types of material degradation, comparable to austenitic stainless steels and cobalt-based alloys. Increasing the alloy content to increase the $\mathrm{DO}_{3}$ to $\mathrm{B} 2$ transformation temperature significantly increases the resistance to both wear and erosion. Extensive disordering occurs as a result of the intense plastic deformation prior to material removal in both wear and erosion.

Fully dense alloys based on $\mathrm{Fe}_{3} \mathrm{Al}$ have been produced by reaction synthesis from low cost elemental powders under an applied pressure using hot pressing, hot isostatic pressing or the Ceracon process during in situ reaction or subsequent to formation of the intermetallic. The reaction proceeds by outward spreading of a transient liquid phase from the initial aluminum particle site and precipitation of the compound phase from the liquid. Combustion synthesized material has a very fine grain size that is resistant to coarsening at high temperature because of a high density of fine oxides from the prior particle boundaries. The fine grain size results in approximately twice the yield strength in the reaction synthesized material compared to hot extruded pre-alloyed powder. Combustion synthesis has also been successfully applied to joining $\mathrm{Fe}_{3} \mathrm{Al}$ and to forming coatings on carbon steel substrates.

Combustion synthesis has been shown to be a viable method for fabricating trialuminides from elemental powder compacts. In this study, nominal compositions of $\mathrm{Al}_{3} \mathrm{Ti}, \mathrm{Al}_{73} \mathrm{Ti}_{24} \mathrm{Cr}_{3}$ and $\mathrm{Al}_{67} \mathrm{Ti}_{25} \mathrm{Cr}_{8}$ were examined. Fully dense, homogeneous materials exhibiting an equiaxed grain structure were produced by conducting the reaction and homogenization under external pressure, or by carrying out reaction and homogenization in a furnace at ambient pressure and subsequently densifying the porous preform by hot consolidation. The tetragonal $\mathrm{DO}_{z 2}$ structure was the primary reaction product for all compositions. Most of the $\mathrm{Cr}$ remained undissolved after reaction and a homogenization heat treatment at $1200^{\circ} \mathrm{C}$ or above was used to put the $\mathrm{Cr}$ into solution and form the desired $\mathrm{L}_{2}$ phase. 


\section{ACKNOWLEDGMENTS}

The authors acknowledge the assistance of W. H. McFerran who participated in this research through the U.S. Department of Energy Teacher Research Associate (TRAC) program. Additional thanks go to V. L. Smith-Wackerle, G. L. Fletcher and K. S. Aldrich for their assistance. 


\section{CONTENTS}

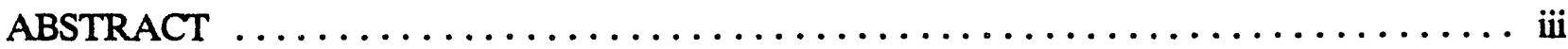

ACKNOWLEDGMENTS $\ldots \ldots \ldots \ldots \ldots \ldots \ldots \ldots \ldots \ldots \ldots \ldots \ldots \ldots \ldots \ldots$

INTRODUCTION $\ldots \ldots \ldots \ldots \ldots \ldots \ldots \ldots \ldots \ldots \ldots \ldots \ldots \ldots \ldots \ldots \ldots$

ABRASIVE WEAR AND EROSION OF Fe $\mathrm{F}_{3} \mathrm{Al} \ldots \ldots \ldots \ldots \ldots \ldots \ldots \ldots \ldots$

COMBUSTION SYNTHESIS OF $\mathrm{Fe}_{3} \mathrm{Al} \ldots \ldots \ldots \ldots \ldots \ldots \ldots \ldots \ldots \ldots \ldots \ldots$

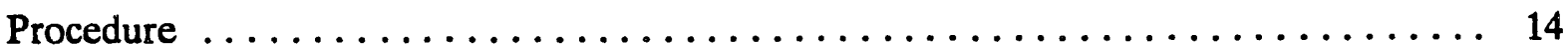

Microstructure and Reaction Mechanism . . . . . . . . . . . . . . 17

Resistance to Grain Growth $\ldots \ldots \ldots \ldots \ldots \ldots \ldots \ldots \ldots \ldots \ldots \ldots \ldots \ldots \ldots$

Mechanical Properties $\ldots \ldots \ldots \ldots \ldots \ldots \ldots \ldots \ldots \ldots \ldots \ldots \ldots \ldots \ldots \ldots \ldots \ldots$

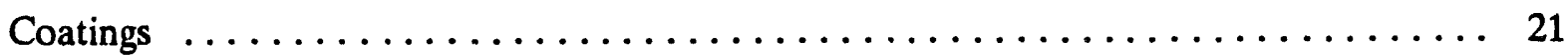

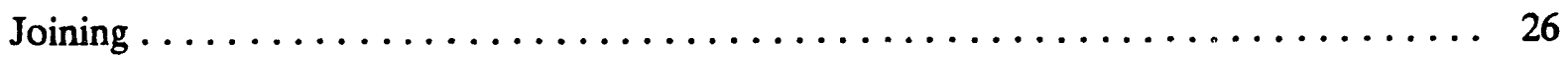

Wear Resistant Particle Reinforced Composites . . . . . . . . . . . . . 26

COMBUSTION SYNTHESIS OF CUBIC $\mathrm{Al}_{3} \mathrm{Ti} \ldots \ldots \ldots \ldots \ldots \ldots \ldots \ldots \ldots$

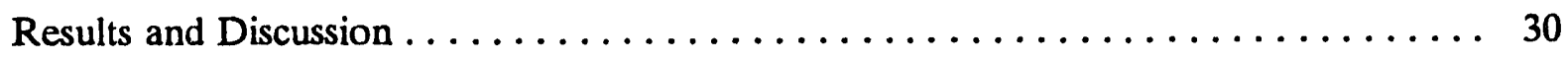

CONCLUSIONS ................................ 39

REFERENCES $\ldots \ldots \ldots \ldots \ldots \ldots \ldots \ldots \ldots \ldots \ldots \ldots \ldots \ldots \ldots \ldots \ldots$

\section{FIGURES}

1. Schematic representation of ultrasonic cavitation test $\ldots \ldots \ldots \ldots \ldots \ldots \ldots \ldots \ldots$

2. Schematic representation of cavitating jet erosion test $\ldots \ldots \ldots \ldots \ldots \ldots \ldots \ldots$

3. Abrasive wear and cavitation erosion rate of alloys based on $\mathrm{Fe}_{3} \mathrm{Al}$ as a function of the critical temperature $\ldots \ldots \ldots \ldots \ldots \ldots \ldots \ldots \ldots \ldots$

4. The 220 fundamental X-ray diffraction peak from abrasive wear debris, erosion debris, and filings showing line broadening $\ldots \ldots \ldots \ldots \ldots \ldots \ldots$ 


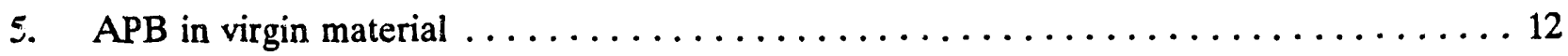

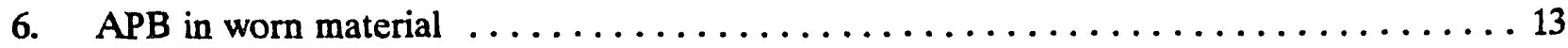

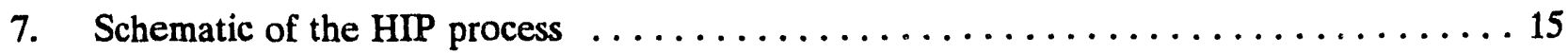

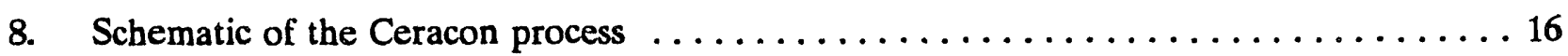

9. DTA scan of the $\mathrm{Fe}_{3} \mathrm{Al}$ combustion synthesis reaction $\ldots \ldots \ldots \ldots \ldots \ldots \ldots \ldots \ldots$

10. X-ray diffraction patterns for (a) the starting elemental powders and

(b) the reaction product after hot pressing $\ldots \ldots \ldots \ldots \ldots \ldots \ldots \ldots \ldots \ldots \ldots \ldots \ldots \ldots \ldots$

11. Optical micrograph of HIPped binary $\mathrm{Fe}_{3} \mathrm{Al}$ with $3 \mu \mathrm{m}$ diameter

aluminum powder in polished and etched condition

12. Grain size as a function of annealing time for combustion synthesized

(SHS) $\mathrm{Fe}_{3} \mathrm{Al}+5 \% \mathrm{Cr}$. Data for traditional ingot metallurgy (I/M) of the

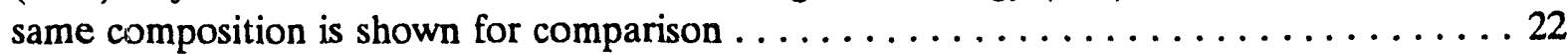

13. Bright field electron micrograph of a solution treated alloy containing $5 \% \mathrm{Cr}$

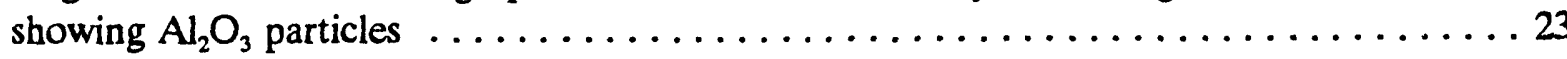

14. Optical micrograph of a combustion synthesized iron aluminide

coating formed on a low carbon steel substrate in the hot press $\ldots \ldots \ldots \ldots \ldots \ldots 25$

15. Optical micrograph of an SHS iron aluminide autogenous joint

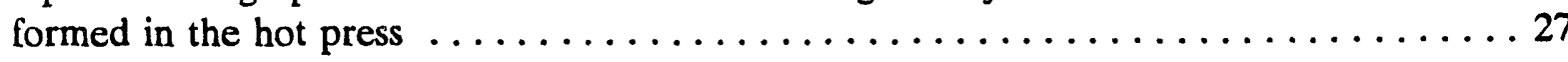

16. Optical micrograph of and $\mathrm{Al}_{2} \mathrm{O}_{3}$ particle reinforced iron aluminide

composite formed by combustion synthesis in the HIP $\ldots \ldots \ldots \ldots \ldots \ldots \ldots \ldots$

17. X-ray diffraction patterns for binary $\mathrm{Al}_{3} \mathrm{Ti}$ and the $8 \% \mathrm{Cr}$ containing

material after heat treatment at $1200^{\circ} \mathrm{C}$

18. DTA traces obtained from $\mathrm{Al}_{3} \mathrm{Ti}, \mathrm{Al}_{73} \mathrm{Ti}_{24} \mathrm{Cr}_{8}$, and $\mathrm{Al}_{67} \mathrm{Ti}_{25} \mathrm{Cr}_{8}$. Note the appearance of the solid state exothermic reaction and the decrease in initiation temperature with increasing $\mathrm{Cr}$ content $\ldots \ldots \ldots \ldots \ldots \ldots \ldots \ldots \ldots \ldots \ldots \ldots$

19. Optical micrographs of an $\mathrm{Al}_{67} \mathrm{Ti}_{25} \mathrm{Cr}_{8}$ sample HIPped at $1100^{\circ} \mathrm{C}$ for $1 \mathrm{~h}$ at $100 \mathrm{MPa}$, homogenized at $1200^{\circ} \mathrm{C}$ for $4 \mathrm{~h}$, then densified by Ceracon consolidation at $1100^{\circ} \mathrm{C}$ and $1240 \mathrm{MPa}$.

Microstructures shown in the as-polished (a), and etched (b) conditions . . . . . . . 36

20. Transmission electron micrograph of $\mathrm{Al}_{67} \mathrm{Ti}_{25} \mathrm{Cr}_{8}$ showing low magnification view of aluminum oxide particles on a grain boundary 
21. Transmission electron micrograph of $\mathrm{Al}_{67} \mathrm{Ti}_{25} \mathrm{Cr}_{8}$ showing high magnification view of lath shaped $\mathrm{Al}_{2} \mathrm{Ti}$ precipitates

\section{TABLES}

1. Abrasive wear and erosion rates and the critical temperatures for several alloys based on $\mathrm{Fe}_{3} \mathrm{Al}$.

2. X-ray diffraction parameters for erosion and abrasion debris and for filings of $\mathrm{Fe}_{3} \mathrm{Al}$

3. Room temperature tensile properties of $\mathrm{Fe}_{3} \mathrm{Al}$ alloyed with chromium and fabricated using self-propagating high temperature synthesis. Data for hot extruded prealloyed powder are included for comparison

4. Material loss rates under abrasive wear conditions for iron aluminindes fabricated using self-propagating high temperature synthesis (SHS) and

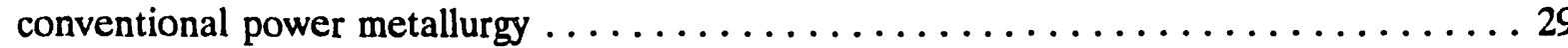

5. Relative densities and phases present in combustion synthesized

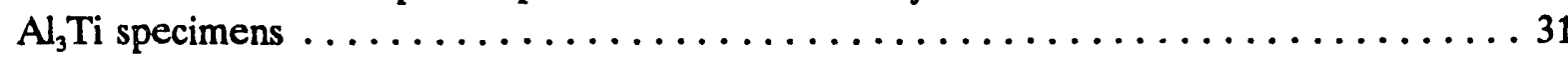




\section{Processing, Properties, and Wear Resistance of Aluminides}

\section{INTRODUCTION}

The failure of components in service can often be attributed to wear, erosion or corrosion-enhanced wear and erosion. For example, cavitation erosion can be a major problem for valves, pumps, hydroturbines and ship propellers. Cavitation occurs in fluids when flow conditions cause a local pressure drop. Collapse of the resulting vapor cavities causes pressure pulses that can damage adjacent surfaces. Damage due to wear is manifested in a variety of ways, such as abrasion in mining operations, galling in valve seats, and failure in sliding machinery. The phenomena contributing to failure under all of these conditions are complex and often specific to the particular application. Material properties determining resistance to wear and erosion are correspondingly complex, making it difficult to predict the service behavior of a particular material. Generally, high hardness, rapid work hardening and good oxidation and corrosion resistance can all contribute to wear and erosion resistance. There is also evidence that long range crystallographic order contributes to increased resistance to cavitation erosion. ${ }^{1}$

Common commercial materials used in severe wear and erosion applications include cobalt-based alloys, high manganese austenitic stainless steels, and other chromium containing alloys. Alloys based on ordered intermetallic compounds, including $\mathrm{Ni}_{3} \mathrm{Al}$ and $\mathrm{Fe}_{3} \mathrm{Al}$, are being investigated as alternative materials for more severe wear and erosion applications. These alloys combine several desirable properties, including increasing yield strength with moderately increasing temperature, high work hardening rates, and resistance to oxidation. In addition, they usually contain only limited amounts of critical and strategic metals as alloying elements.

Alloys based on $\mathrm{Fe}_{3} \mathrm{Al}$ have been extensively studied to determine wear and erosion behavior, as well as conventional mechanical properties. ${ }^{2-4}$ Processing $\mathrm{Fe}_{3} \mathrm{Al}$ using a number of different methods, including casting, hot rolling and conventional powder metallurgy, has been investigated. ${ }^{5,6}$ Conventional hot working techniques are applicable to forming low alloy materials based on $\mathrm{Fe}_{3} \mathrm{Al}$; however, alloys containing $\mathrm{Mo}$ and $\mathrm{Ti}$ for improved high temperature strength are difficult to hot roll because of brittle failure resulting from heat loss to the rolls. ${ }^{7}$ Hot extrusion of pre-alloyed powders has been investigated to examine the possible property improvements resulting from refined microstructures. ${ }^{6}$ Casting into complex shapes has not been systematically investigated; however, the limited work that has been done indicates that there may be some difficulties with brittle behavior in cast structures.

It has been shown that tensile testing binary $\mathrm{Fe}_{3} \mathrm{Al}$ in vacuum or dry argon significantly increases the room temperature ductility compared to material tested in laboratory air or water vapor saturated gas. ${ }^{8.9}$ The cause of embrittlement inferred from these results is the reaction of aluminum at the crack tip to form aluminum oxide and atomic hydrogen. The atomic hydrogen is presumed to be taken up in the lattice, lowering the bond strength, and giving rise to brittle behavior. Addition of 2 to $5 \% \mathrm{Cr}$ has resulted in tensile ductility up to $20 \%$ at ambient temperature and reduced the influence of the testing environment. ${ }^{4,8}$ Chromium is thought to alter the reaction of water at the crack tip and reduce the formation of atomic hydrogen. 
An alternative processing method, known as reactive sintering, combustion synthesis or self-propagating high temperature synthesis, has been shown applicable to synthesis of $\mathrm{Fe}_{-3} \mathrm{Al}$ and several other aluminides. ${ }^{10-14}$ Combustion synthesis is a potentially useful technique for producing structural intermetallic compounds and composites using an exothermic reaction between elemental powders to form the intermetallic by an exothermic reaction e.g.,:

$$
3 \mathrm{Fe}+\mathrm{Al}>\mathrm{Fe}_{3} \mathrm{Al} \text {. }
$$

This approach has been used to fabricate a variety of aluminides, including those of nickel, ${ }^{12}$ iron, ${ }^{10}$ niobium ${ }^{15}$ and titanium. ${ }^{13,14}$ In these cases the exothermic reaction is typically initiated near the melting point of aluminum and maximum combustion temperatures may be either above or below the melting point of the product phase. When the combustion temperature exceeds the melting point of the product, e.g. in the case of $\mathrm{NiAl}$, a cast structure is usually obtained. Alternatively, in cases where the combustion temperature is below the melting point of the product, e.g. for $\mathrm{Ni}_{3} \mathrm{Al}$ or $\mathrm{Fe}_{3} \mathrm{Al}$, the reactions typically proceed by the formation and spreading of a transient aluminum-rich liquid phase, followed by precipitation of the compound. ${ }^{10.12}$ The advantages of this process, compared to conventional methods, include the use of inexpensive and easily compacted elemental powders, low processing temperatures, near net-shape fabrication, and considerable flexibility in composition and microstructure control, including the ability to incorporate particulate reinforcements that may lead to improved wear resistance.

Alloys based on $\mathrm{Al}_{3} \mathrm{Ti}$ are attractive candidates for structural applications at elevated temperature because of their low density, high melting point and excellent resistance to oxidation. Binary $\mathrm{Al}_{3} \mathrm{Ti}$ has an ordered tetragonal crystal structure $\left(\mathrm{DO}_{2}\right)$ that is thought to be intrinsically brittle due to an insufficient number of slip systems. It has been demonstrated that alloying of $\mathrm{Al}_{3} \mathrm{Ti}$ with fourth period transition elements results in transformation of the tetragonal structure to the cubic $\mathrm{L1}_{2}$ structure, which has a sufficient number of slip systems for plasticity. ${ }^{16-20}$ While significant room temperature tensile ductility has not yet been demonstrated for the cubic trialuminide materials, hardness and compression testing have indicated ductility improvements. ${ }^{17-19,21,22}$ By analogy with other intermetallics, $\mathrm{Al}_{3} \mathrm{Ti}$ with the $\mathrm{L1}_{2}$ structure is also expected to exhibit excellent wear resistance.

Cubic $\mathrm{Al}_{3} \mathrm{Ti}$ has been fabricated by conventicnal casting, ${ }^{19,21}$ melt spinning, ${ }^{23}$ solid state processing of elemental powders ${ }^{24,25}$ and plasma deposition. ${ }^{18} \mathrm{Al}_{3} \mathrm{Ti}$ is a line compound, exhibiting little or no range of solubility. Thus, fabrication of dense, homogeneous, single phase material suitable for mechanical property evaluations has been problematic. ${ }^{19,21,25}$ Most castings and powder products have been subjected to hot consolidation subsequent to initial processing in order to eliminate segregation, pores and other defects. ${ }^{16-19,21}$

It is well known that elemental titanium and aluminum powder mixtures will react exothermically at elevated temperatures to form intermetallic compounds. ${ }^{26}$ Previous studies have examined the fabrication of TiAl and particle reinforced TiAl composites using combustion synthesis; $;^{13,14}$ it has generally been observed that external pressure must be applied, either during or subsequent to the reaction, in order to produce dense products. No detailed studies have yet been reported for the production of $\mathrm{Al}_{3} \mathrm{Ti}$ by exothermic reaction. Microstructure and property characterizations of ternary $\mathrm{Al}_{3} \mathrm{Ti}$ materials prepared from elemental powders have been 
reported; $;^{16,17.25}$ however, processing methods were not described in detail, and reaction mechanisms were not studied.

This report briefly reviews the results of experiments in our laboratory characterizing the wear and erosion resistance of both cast and conventional powder metallurgy alloys based on $\mathrm{Fe}_{3} \mathrm{Al}$. The mechanism of reaction and the relationship of processing variables to microstructure and properties, including wear resistance, of $\mathrm{Fe}_{3} \mathrm{Al}$ based alloys and pasticulatie reinforced composites produced by combustion synthesis will be presented. Preliminary experimental results on use of combustion synthesis to fabricate fully dense $\mathrm{Al}_{3} \mathrm{Ti}$ alloys will be described in the final section. 


\section{ABRASIVE WEAR AND EROSION OF $\mathrm{Fe}_{3} \mathrm{AI}$}

Cavitation erosion testing was performed in distilled water at $20^{\circ} \mathrm{C}$ with an ultrasonic transducer coupled to a titanium-tipped exponential horn vibrating at $20 \mathrm{kHz}$, in accordance with the ASTM standard technique. ${ }^{27}$ The flat tip, with a surface area of $1 \mathrm{~cm}^{2}$, was maintained at a stand-off distance of $0.61 \mathrm{~mm}$. Mass loss measurements were made every $900 \mathrm{~s}$ until a steady state mass loss rate was reached; thereafter the interval was increased to $3 \mathrm{~h}$. The total test time was typically $30 \mathrm{~h}$. Additional tests were conducted using a cavitating jet erosion technique with the pressure of the water jet maintained at $42 \mathrm{MPa}$. This test method has been used extensively to characterize commercial alloys for erosion applications and permits the properties of several aluminides to be compared with commercial alloys tested under identical conditions. ${ }^{23}$ A detailed comparison of the two methods of erosion testing has been reported previously. ${ }^{29}$ Schematic illustrations of the two types of erosion tests are shown in Figure 1 and Figure 2.

Abrasive wear testing was conducted according to ASTM standard techniques ${ }^{30.31}$ using flowing 60 mesh dry sand abrasive applied through a loaded rubber wheel. The test conditions were carefully standardized with respect to the load $(5 \mathrm{~kg})$ and speed $\left(230 \mathrm{rev} \mathrm{min}^{-1}\right)$ of the wheel (22.9 cm diameter and $1.3 \mathrm{~cm}$ thick) and the flow rate of abrasive $\left(4.2 \mathrm{~mL} \mathrm{~s}^{-1}\right)$. Wrought Type 316 stainless steel was tested prior to each series of aluminide samples, as well as periodically between samples, as a standard to minimize systematic testing errors. The mass loss was measured at $90 \mathrm{~s}$ intervals to a total test time of $540 \mathrm{~s}$.

For compositions near stoichiometry, $\mathrm{Fe}_{3} \mathrm{Al}$ has three possible equilibrium crystal structures. From room temperature up to a critical temperature of approximately $550^{\circ} \mathrm{C}$, the $\mathrm{DO}_{3}$ ordered fcc structure is stable. Above the critical temperature for the $\mathrm{DO}_{3}$ structure, an imperfect simple cubic B2 crystal structure exists. The B2 structure transforms to a random body centered cubic structure above approximately $1000^{\circ} \mathrm{C}$. There is also a maximum in the yield strength of the material rear the critical temperature for the $\mathrm{DO}_{3}$ to $\mathrm{B} 2$ transformation. ${ }^{32}$ Recently, it has been shown tha: the transformation temperature can be increased significantly by alloying. ${ }^{33.34}$ The abrasive wear and erosion rates for several alloys based on $\mathrm{Fe}_{3} \mathrm{Al}$ are given in Table 1 along with the change in critical temperature compared with the base alloy. The strong correlation between the critical ordering transformation temperature and the abrasive wear and erosion rates is shown in Figure 3. It is also important to note that the alloys based on $\mathrm{Fe}_{3} \mathrm{Al}$ have significantly greater resistance to abrasive wear than either the nickel aluminides or Type 304 stainless steel. ${ }^{1}$ In addition, alloying the iron aluminides gave the most erosion-resistant material.

In order to understand the mechanisms involved in cavitation erosion and abrasive wear, the debris formed by erosion and abrasion of the cast binary alloy was collected and analyzed using SEM and $\mathrm{x}$-ray diffraction. Of particular interest is the fact that $\mathrm{x}$-ray diffraction can be used to examine not only the amount of plastic deformation that the material has undergone based on the residual dislocation density and other defects, but also the degree to which the order has been destroyed.

Particles of the erosion debris were collected in the bottom of the container holding the cavitating water. These were very fine particles, on the order of $3 \mu \mathrm{m}$ in size. The superlattice peaks that were strong in the undeformed material were no longer detectable and the 


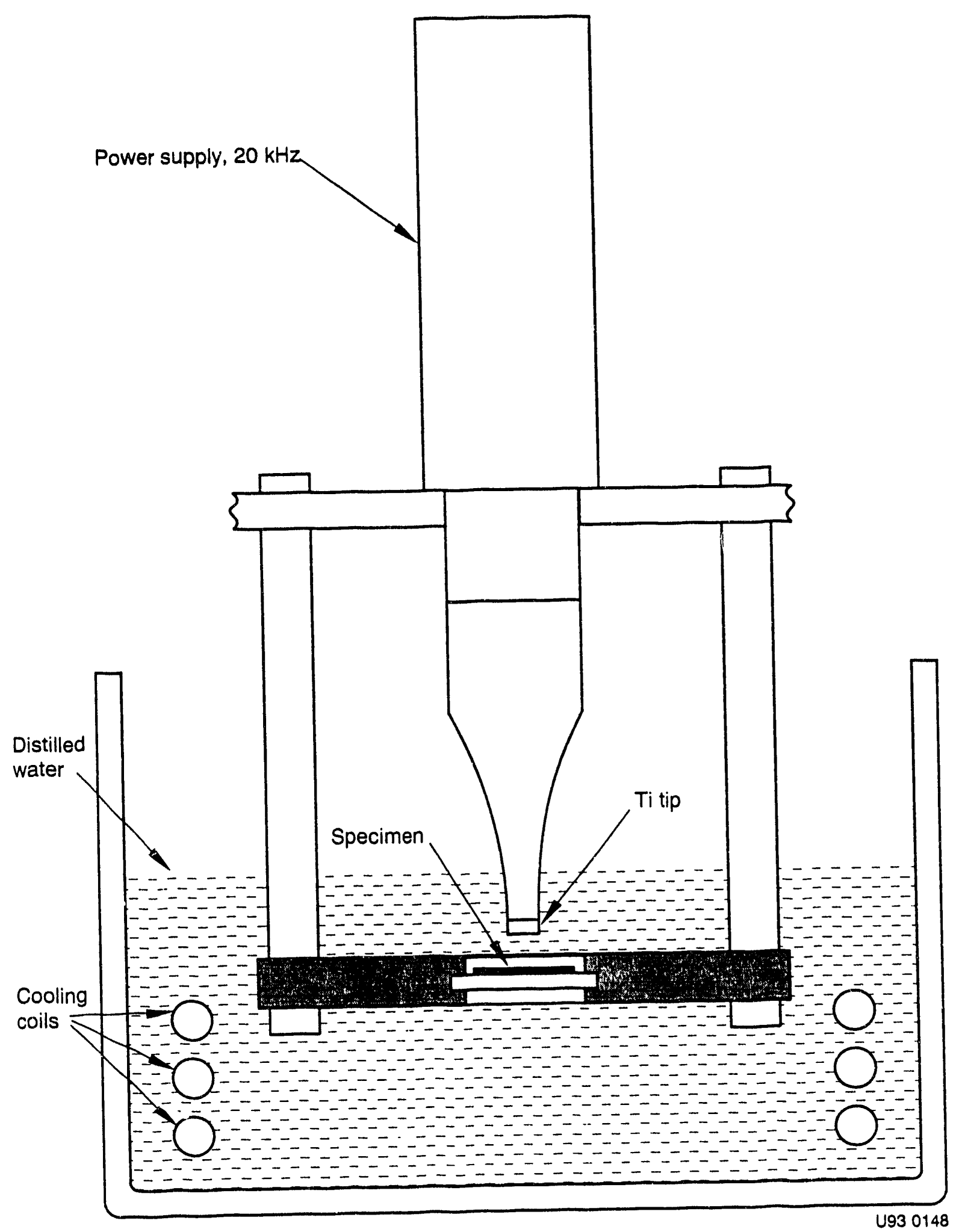

Figure 1. Schematic representation of ultrasonic cavitation test. 


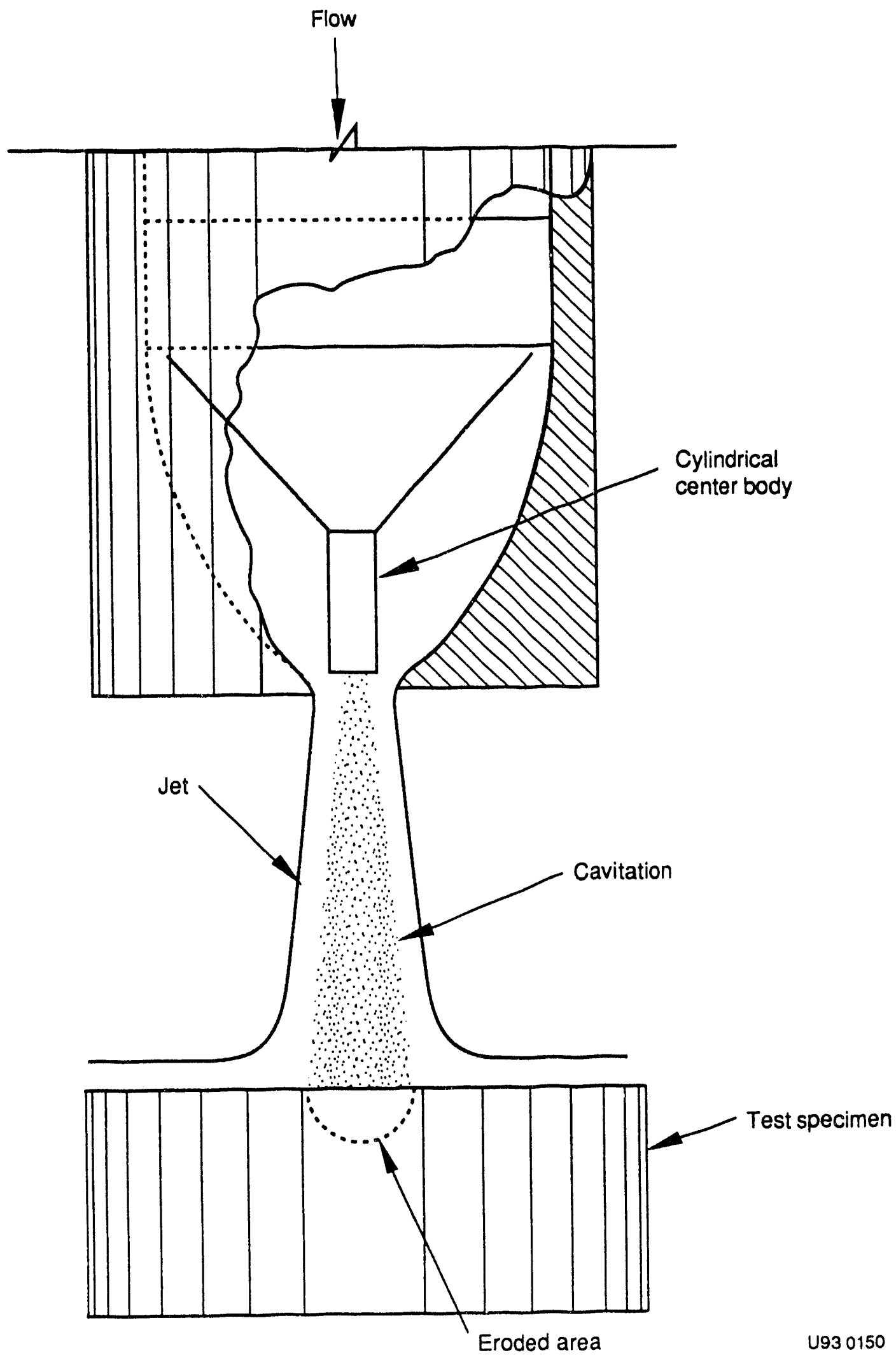

Figure 2. Schematic representation of cavitating jet erosion test. 
Table 1. Abrasive wear and erosion rates and the critical temperatures for several alloys based on $\mathrm{Fe}_{3} \mathrm{Al}$.

\begin{tabular}{|c|c|c|c|c|c|c|c|c|}
\hline \multirow[b]{2}{*}{ Material } & \multicolumn{4}{|c|}{ Composition } & \multirow{2}{*}{$\begin{array}{l}\text { Abrasion } \\
\text { rate } \\
(\mathrm{g} / \mathrm{min})\end{array}$} & \multirow{2}{*}{$\begin{array}{c}\text { Erosion } \\
\text { rate } \\
(\mathrm{mg} / \mathrm{h})\end{array}$} & \multirow{2}{*}{$\begin{array}{l}\text { Incubation } \\
\text { time } \\
\text { (h) }\end{array}$} & \multirow[b]{2}{*}{$\begin{array}{c}\mathrm{T}_{\mathrm{c}} \\
\left({ }^{\circ} \mathrm{C}\right)\end{array}$} \\
\hline & Al & Hf & Mo & $\mathbf{T i}$ & & & & \\
\hline A-1 & 28.0 & - & - & 0.1 & 0.0578 & 2.38 & 5.17 & 531 \\
\hline$A-2$ & 28.2 & - & 1.9 & - & 0.0595 & 2.49 & 3.40 & 566 \\
\hline A-5 & 27.4 & - & 0.2 & 4.6 & 0.0471 & 0.84 & 503 & 660 \\
\hline A-19 & 26.0 & 0.2 & 1.9 & 3.9 & 0.0486 & 0.83 & 5.75 & 698 \\
\hline A-22 & 26.5 & 0.08 & 1.0 & 1.7 & 0.0495 & 0.96 & 4.69 & 595 \\
\hline A-25 & 29.4 & 0.07 & 2.2 & 4.2 & 0.0422 & 0.46 & 8.96 & $658 *$ \\
\hline A-28 & 23.2 & 0.10 & 3.9 & 8.2 & 0.342 & 0.83 & - & 784 \\
\hline A-35 & 30.5 & 0.05 & 4.3 & 8.0 & 0.0276 & - & - & 850 \\
\hline A-81 & 30.1 & 0.14 & 2.1 & 4.2 & 0.0421 & 0.59 & 6.83 & - \\
\hline A-87 & 24.5 & 0.11 & 3.2 & 5.6 & 0.0528 & 0.83 & 2.24 & 785 \\
\hline Type 304 SS & - & - & - & - & 0.0967 & 7.82 & 0.80 & - \\
\hline Type 316 SS & - & - & - & - & 0.0967 & 7.82 & 0.80 & - \\
\hline
\end{tabular}




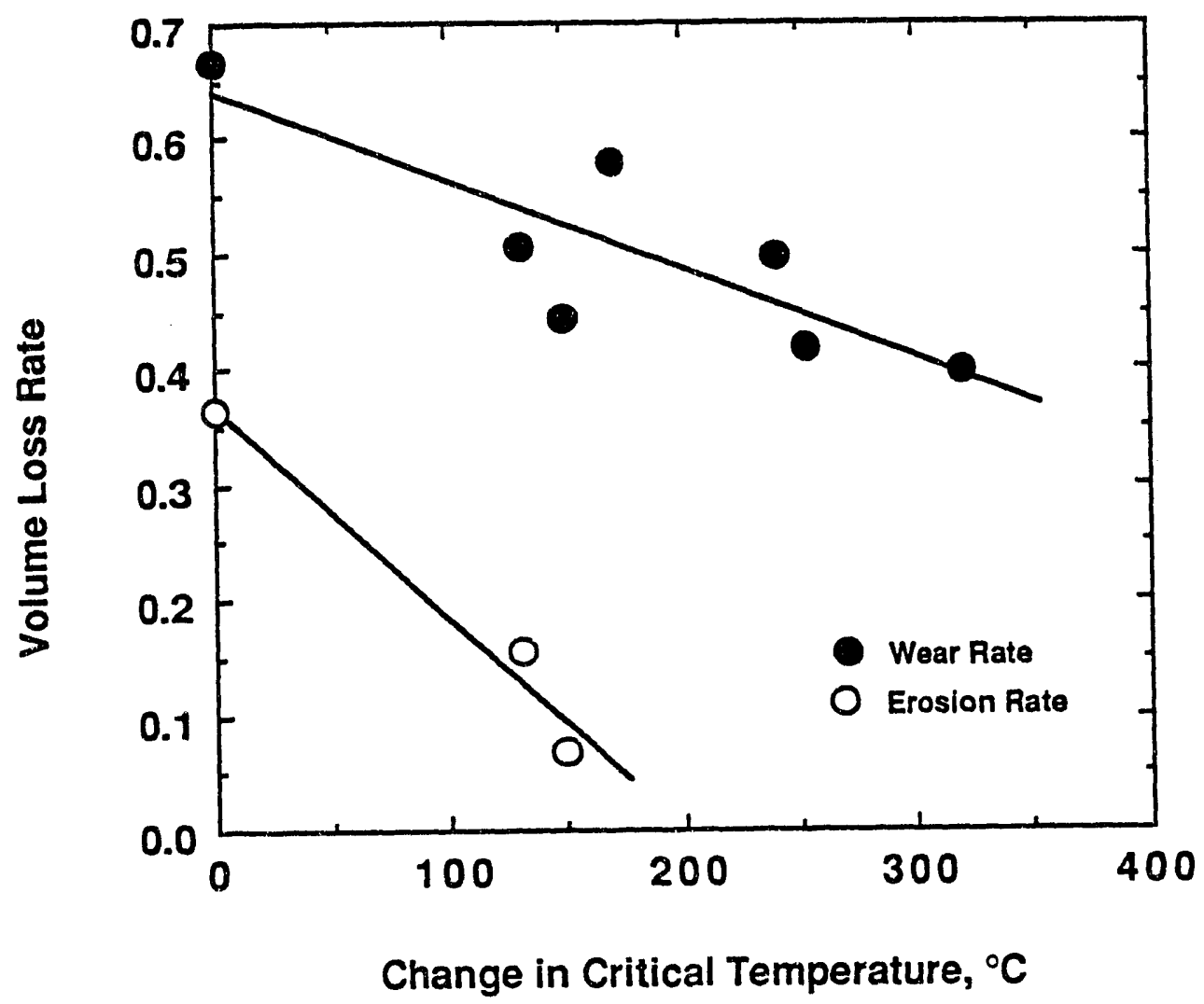

Figure 3. Abrasive wear and cavitation erosion rate of alloys based on $\mathrm{Fe}_{3} \mathrm{Al}$ as a function of the critical temperature. 
fundamental peaks were considerably broadened. Collecting and separating the abrasion debris was much more difficult because it was mixed with large amounts of fine $\mathrm{SiO}_{2}$ from the abrasive. It was not possible to effect a complete separation; the diffraction patterns had overlapping peaks from $\mathrm{Fe}_{3} \mathrm{Al}$ and $\mathrm{SiO}_{2}$. The superiattice lines were also completely absent in the abrasion debris. Examples of the 220 fundamental peak from the erosion and abrasion debris are shown in Figure 4 along with data from a powder formed by the severe deformation process of filing. It is clear from the broadening of the fundamental peaks that the erosion process involves large amounts of plastic deformation, as opposed to brittle fracture. It can also be seen that the erosion process does not produce fundamental peaks quite as broad as abrasion or filing; however, the latter two processes result in very similar defect densities. A summary of quantitative measurements from the debris is shown in Table 2.

The loss of superlattice peaks and the very high dislocation densities make it clear that material removal in these processes occurs through large-scale plastic flow before ultimate fracture. It might be expected that the abrasion and filing results would be similar because the processes are similar in that both involve a machining-type component (the $\mathrm{SiO}_{2}$ particles and the file teeth, respectively). With erosion, there is general impact damage from bubble collapse, but also there are opportunities for localized deformation and damage once the surface begins to erode. These observations emphasize the importance that order can have in determining the resistance of a material to erosion and abrasion. Energy is absorbed in the disordering process, so that the more stable an ordered intermetallic is, the greater the energy needed to disorder the material. The great influence of increasing the critical temperature in the modified iron aluminides on erosion and abrasion resistance is certainly in agreement with these ideas.

TEM examination of the damage region under the wear surfaces has shown that in the initial stages of material damage single dislocations, rather than superlattice dislocation groups, cause plastic flow. Figure 5 and Figure 6 show antiphase boundaries in virgin and wear damaged material, respectively. It is evident from the dramatic change in the morphology of the antiphase boundaries from isotropic to highly elongated that there has been considerable plastic flow. There are a number of single screw dislocations visible at the ends of the elongated antiphase boundaries in Figure 6. This is further evidence that the majority of disordering occurs through plastic flow, rather than as a result of thermal processes. 


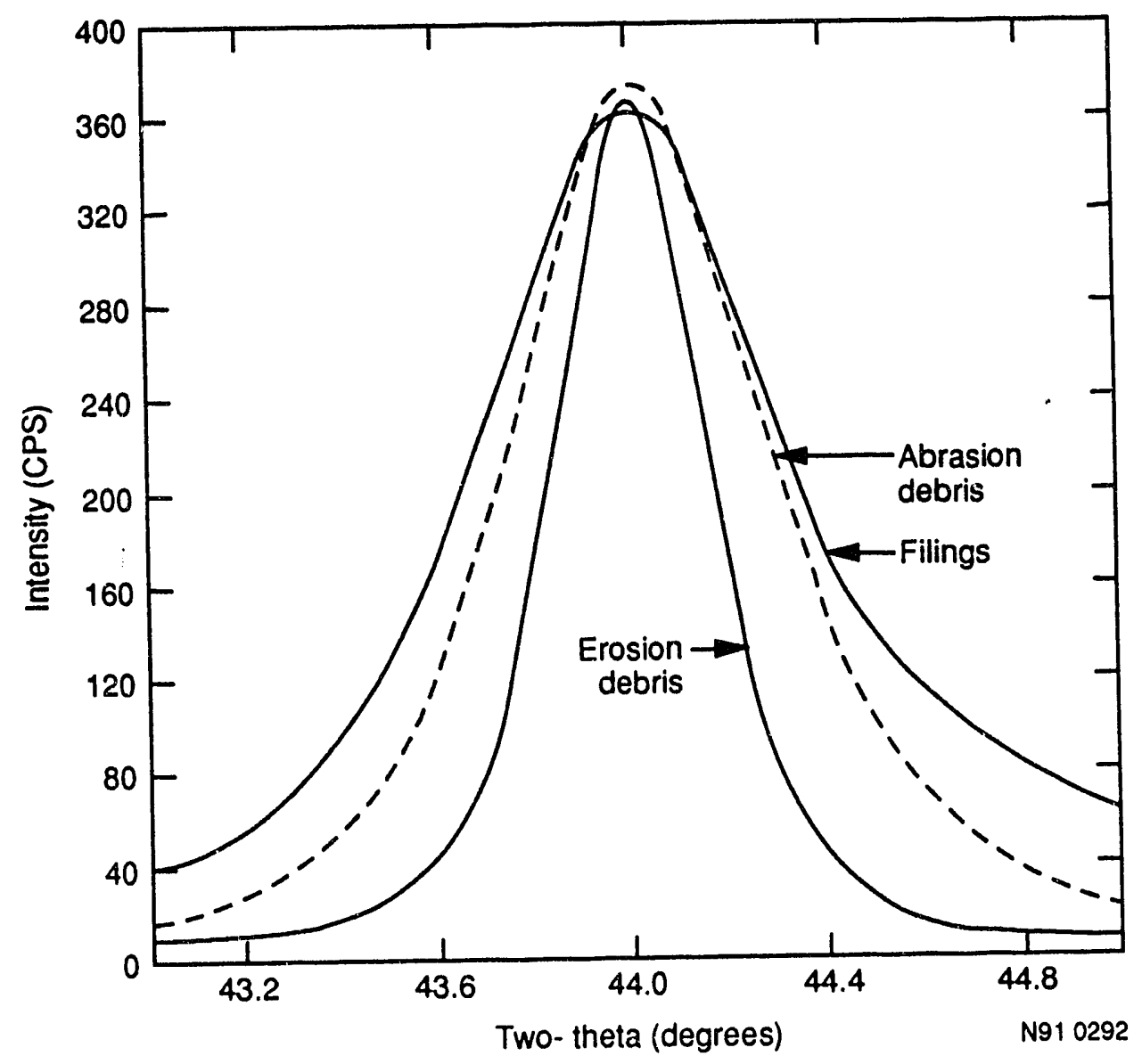

Figure 4. The 220 fundamental $X$-ray diffraction peak from abrasive wear debris, erosion debris, and filings showing line broadening. 
Table 2. X-ray diffraction parameters for erosion and abrasion debris and for filings of $\mathrm{Fe}_{3} \mathrm{Al}$.

\begin{tabular}{lccc}
\multicolumn{1}{c}{ Sample } & $\begin{array}{c}\text { Particle size } \mathrm{D}_{220} \\
(\mathrm{~A})\end{array}$ & $\begin{array}{c}\text { Microstrain } \\
\leq \epsilon_{\mathrm{s} 04}^{2}>^{1 / 2}\end{array}$ & $\begin{array}{c}\text { Estimated } \\
\text { dislocation density } \\
\left(\mathrm{cm} / \mathrm{cm}^{3}\right)\end{array}$ \\
\hline Cavitation erosion debris & 370 & 0.0035 & $3.92 \times 10^{11}$ \\
Abrasion debris & $\sim 170$ & $\sim 0.0053$ & $\sim 1.29 \times 10^{12}$ \\
Filings & 170 & 0.0053 & $1.29 \times 10^{12}$ \\
\hline
\end{tabular}




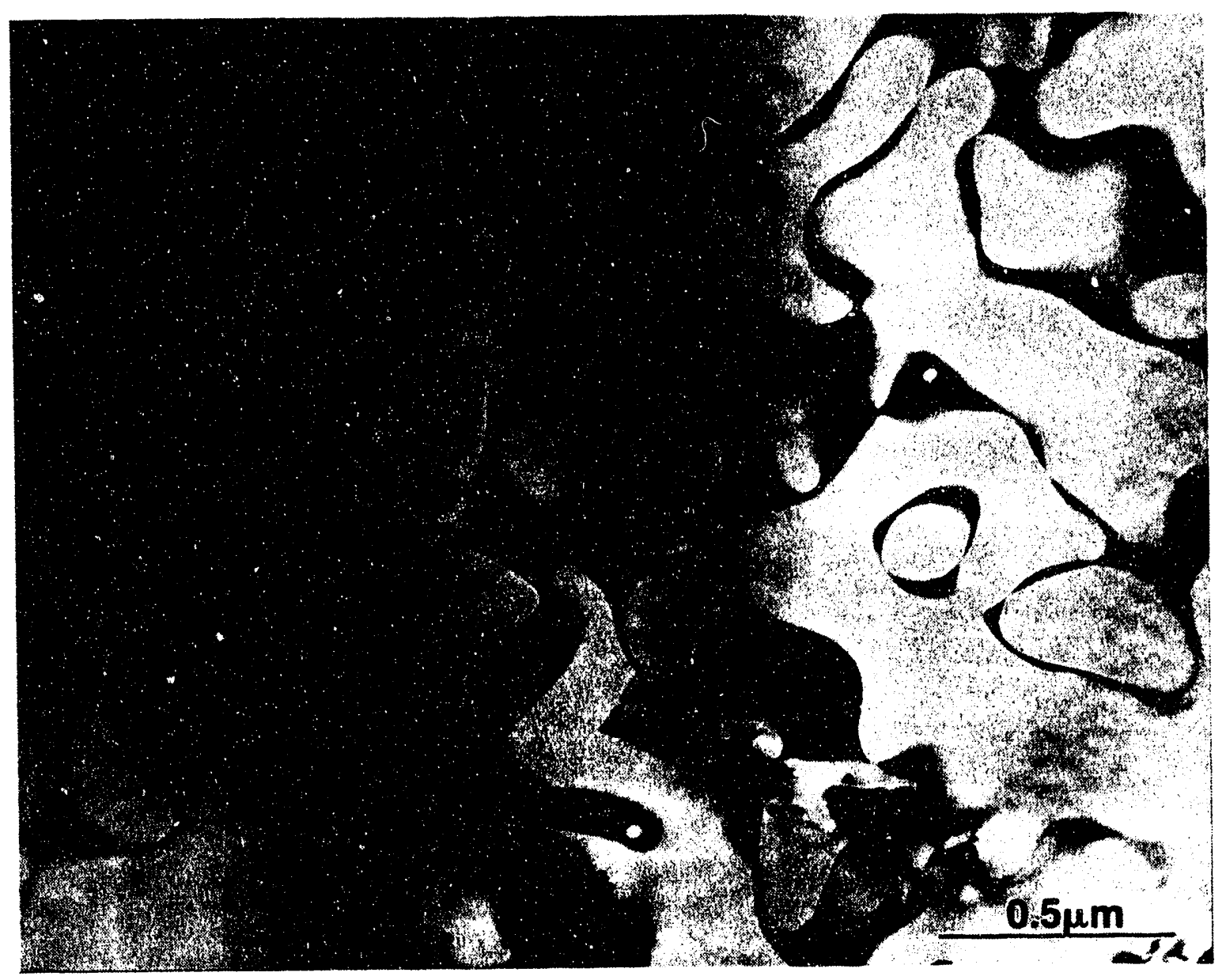

Figure 5. $A P B$ in virgin material. 


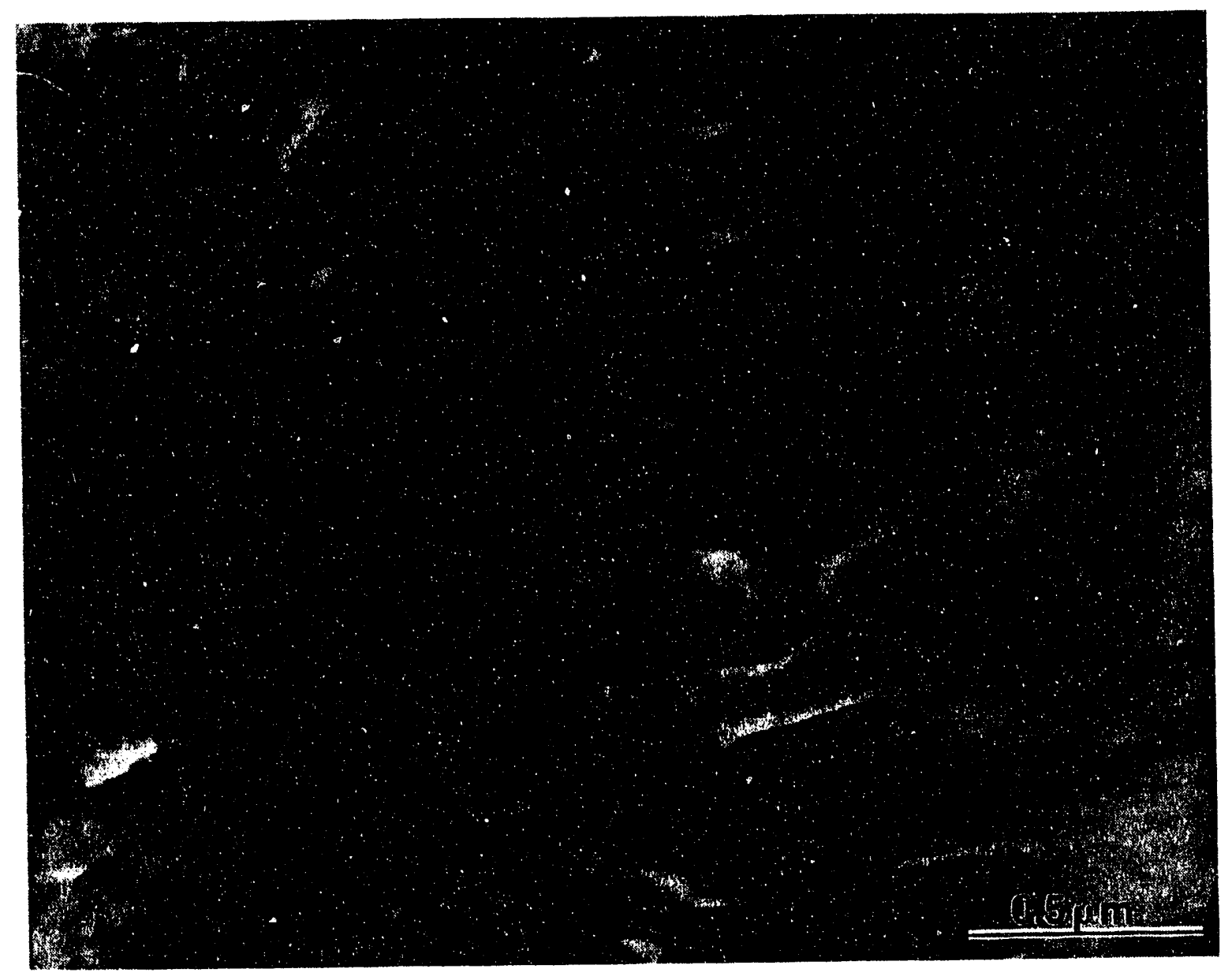

Figure 6. APB in worn material. 


\section{COMBUSTION SYNTHESIS OF $\mathrm{Fe}_{3} \mathrm{AI}$}

Combustion synthesis of $\mathrm{Fe}_{3} \mathrm{Al}$ is somewhat difficult; swelling of compacts accompanying reaction synthesis has been reported in many cases. ${ }^{35}$ Careful selection of the relative particle sizes, green density and heating rate can result in densification compared to the green state; however, the application of pressure is necessary to achieve full density. ${ }^{10}$ It has been found that elemental $\mathrm{Cr}$ does not go into solution during the formation of $\mathrm{Fe}_{3} \mathrm{Al}$ by combustion synthesis. ${ }^{11}$ A solution treatment of several hours is necessary to homogenize the material after formation of the compound. If the solution treatment is carried out subsequent to consolidation, Kirkendall pores form at the prior sites of the $\mathrm{Cr}$ particles. It is therefore desirable to react the powders and homogenize the material prior to consolidation, or maintain the pressure while holding the material at a temperature well above that necessary to carry out the synthesis reaction to allow dissolution of the $\mathrm{Cr}$.

To overcome the limited high temperature mechanical properties of $\mathrm{Fe}_{3} \mathrm{Al}$, while retaining the environmental resistance, the possibility of fabricating $\mathrm{Fe}_{3} \mathrm{Al}$ coatings on conventional steels using combustion synthesis has been investigated. Preliminary results will also be presented on the use of combustion synthesis to join $\mathrm{Fe}_{3} \mathrm{Al}$ with lower heat input than conventional fusion welding.

\section{Procedure}

Carbonyl iron powder with an average particle size of $8 \mu \mathrm{m}$ was mixed in the appropriate ratio with helium gas atomized aluminum powders in all of the experiments. Initial experiments were carried out using $3 \mu \mathrm{m}$ average diameter aluminum powder; however, agglomeration occurred during mixing that resulted in large defects in the consolidated material. Aluminum powder with $10 \mu \mathrm{m}$ average diameter was used in subsequent experiments and agglomeration was not observed. Binary $\mathrm{Fe}-28 \% \mathrm{Al}$ (compositions in atomic percent) and $\mathrm{Fe}-28 \% \mathrm{Al}$ with 2 and 5\% $\mathrm{Cr}$ added were examined. The $\mathrm{Cr}$ was added to the elemental $\mathrm{Fe}$ and $\mathrm{Al}$ powders prior to mixing in the form of 1 to $5 \mu \mathrm{m}$ diameter elemental powder.

Appropriate powders were dry mixed in a shaker-tyre mixer for $1 \mathrm{~h}$ and cold isostatically pressed at $207 \mathrm{MPa}$ to a green density of approximately $70 \%$. Consolidation was carried out using uniaxial hot pressing, HIP or the Ceracon process. ${ }^{36}$ Hot pressing was used to fabricate coatings and reaction synthesized joints by in situ reaction of elemental powders of binary composition under an applied pressure of $50 \mathrm{MPa}$. For HIP consolidation, the green compacts were canned in evacuated $\mathrm{Ni}$ or stainless steel containers prior to consolidation. HIPping was carried out by preheating below the reaction temperature and pressurizing to $138 \mathrm{MPa}$, followed by simultaneously increasing the temperature and pressure to as high as $1100^{\circ} \mathrm{C}$ and $207 \mathrm{MPa}$, respectively. Several processing schedules were examined using the Ceracon process and either in situ reaction or pre-reaction and homogenization at ambient pressure followed by consolidation. The HIP and Ceracon processes are shown schematically in Figure 7 and Figure 8, respectively.

The microstructure of consolidated materials was examined using optical and transmission electron microscopy and $\mathrm{x}$-ray diffraction. Average grain diameters were determined by comparing several micrographs for each sample to the ASTM standard series of 


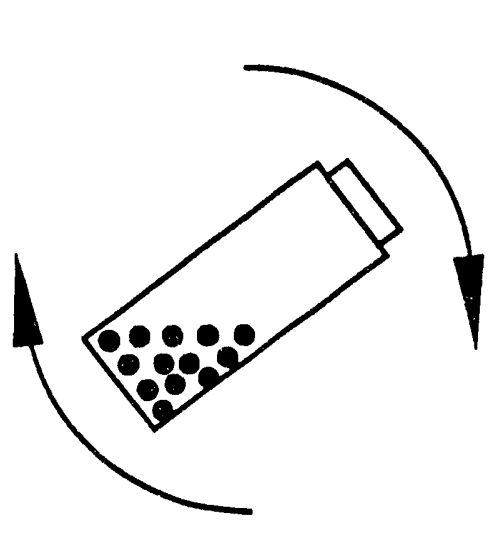

1. Mix powders

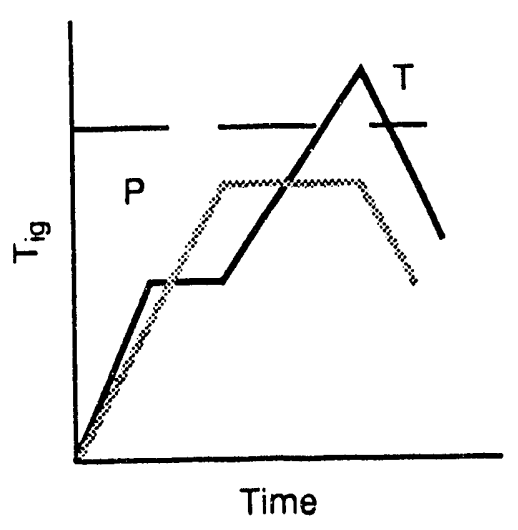

5. Combustion/HIP
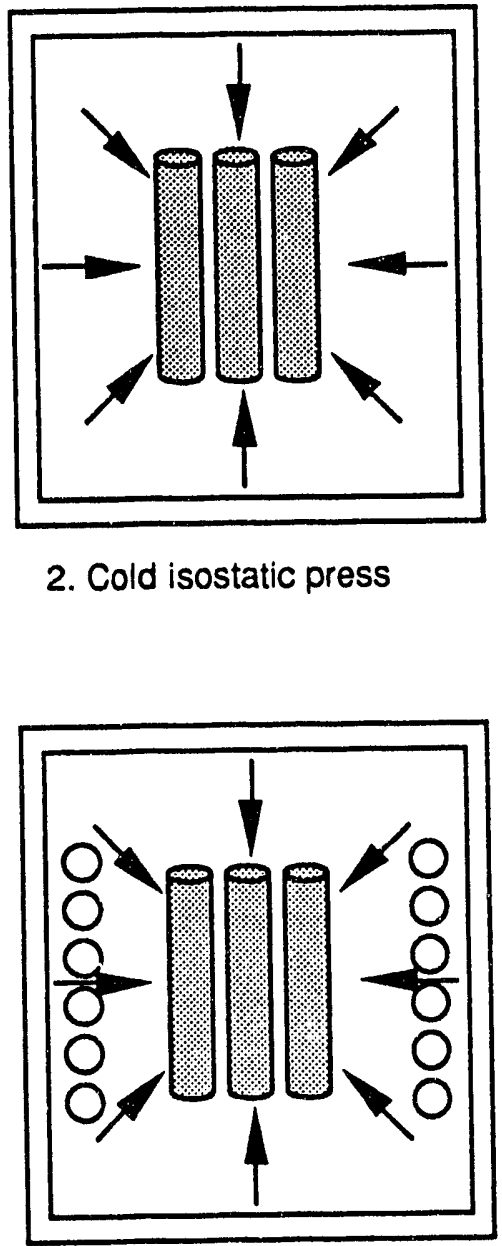

2. Cold isostatic press

4. Evacuate and seal

Figure 7. Schematic of the HIP process. 


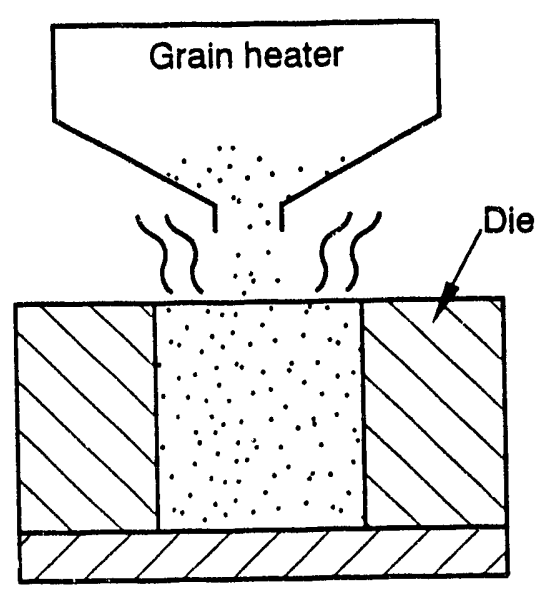

1. Fill die

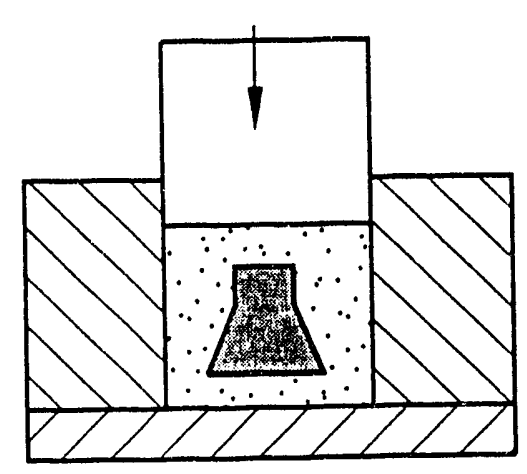

3. Press

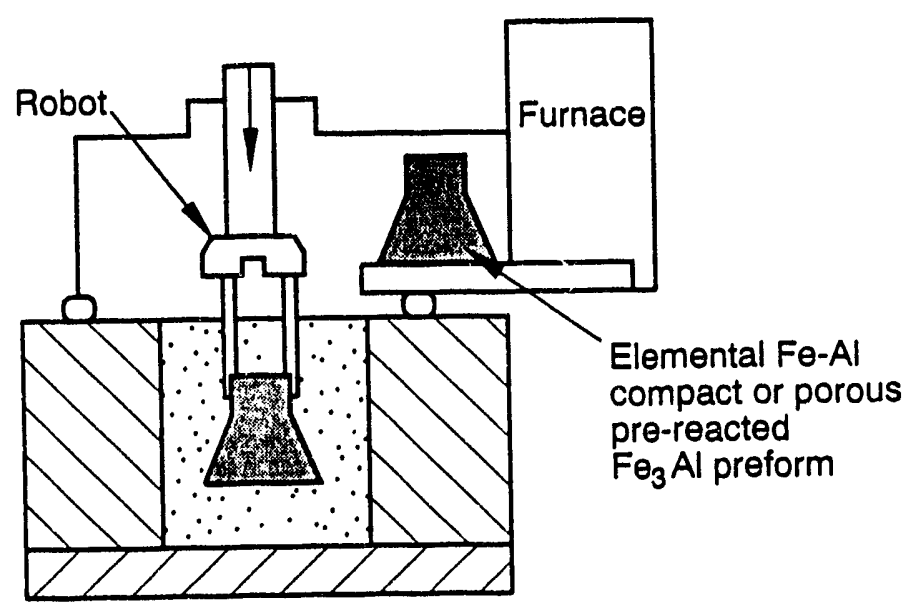

2. Load part
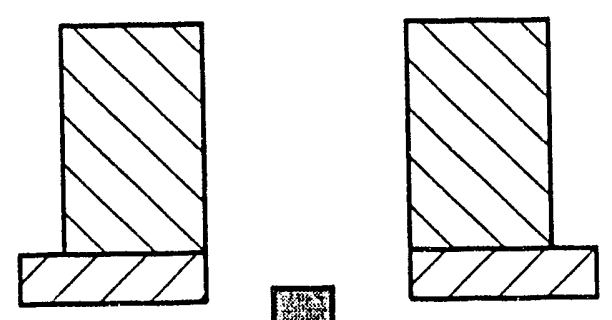

3x-

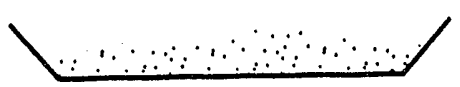

4. Clean die, recycle grain

U93 0149

Figure 8. Schematic of the Ceracon process. 


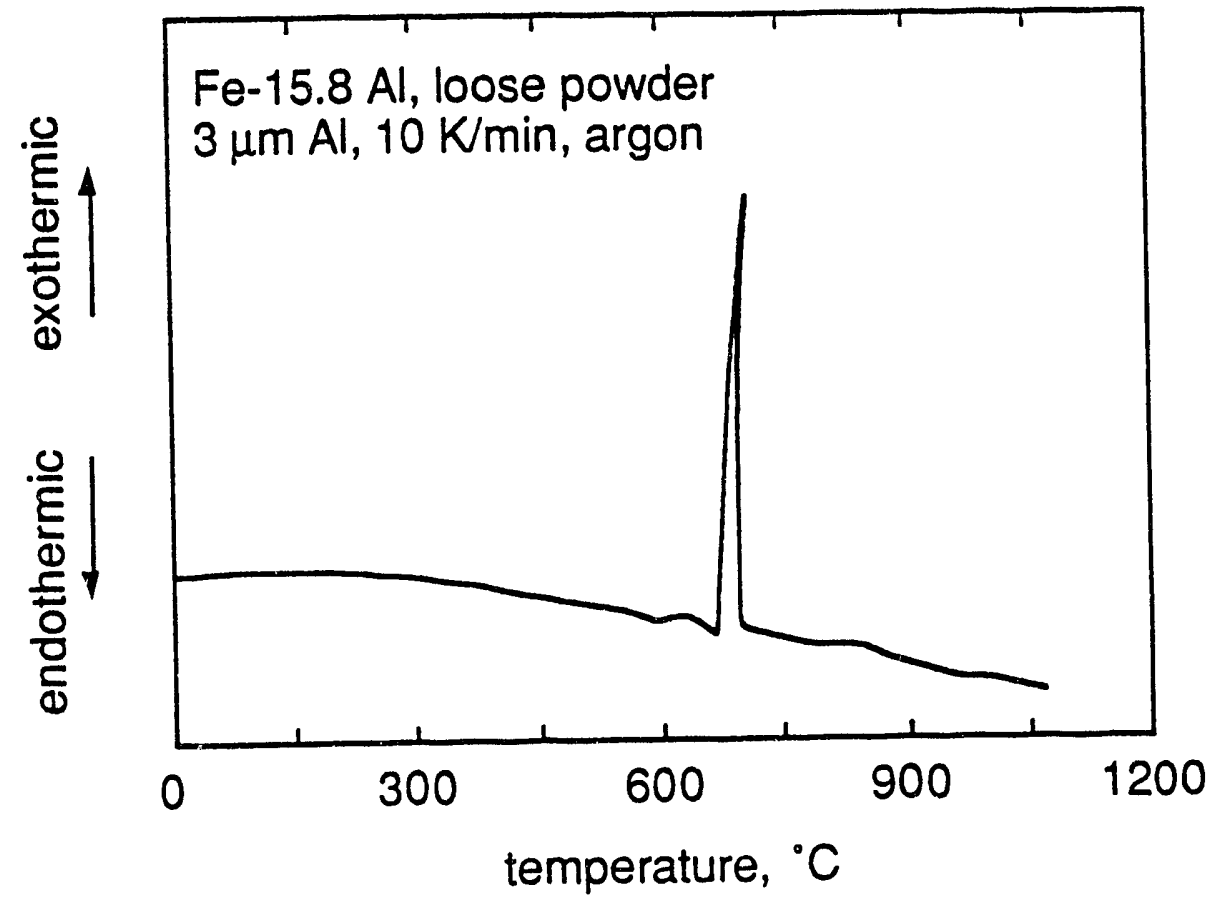

Figure 9. DTA scan of the $\mathrm{Fe}_{3} \mathrm{Al}$ combustion synthesis reaction. 


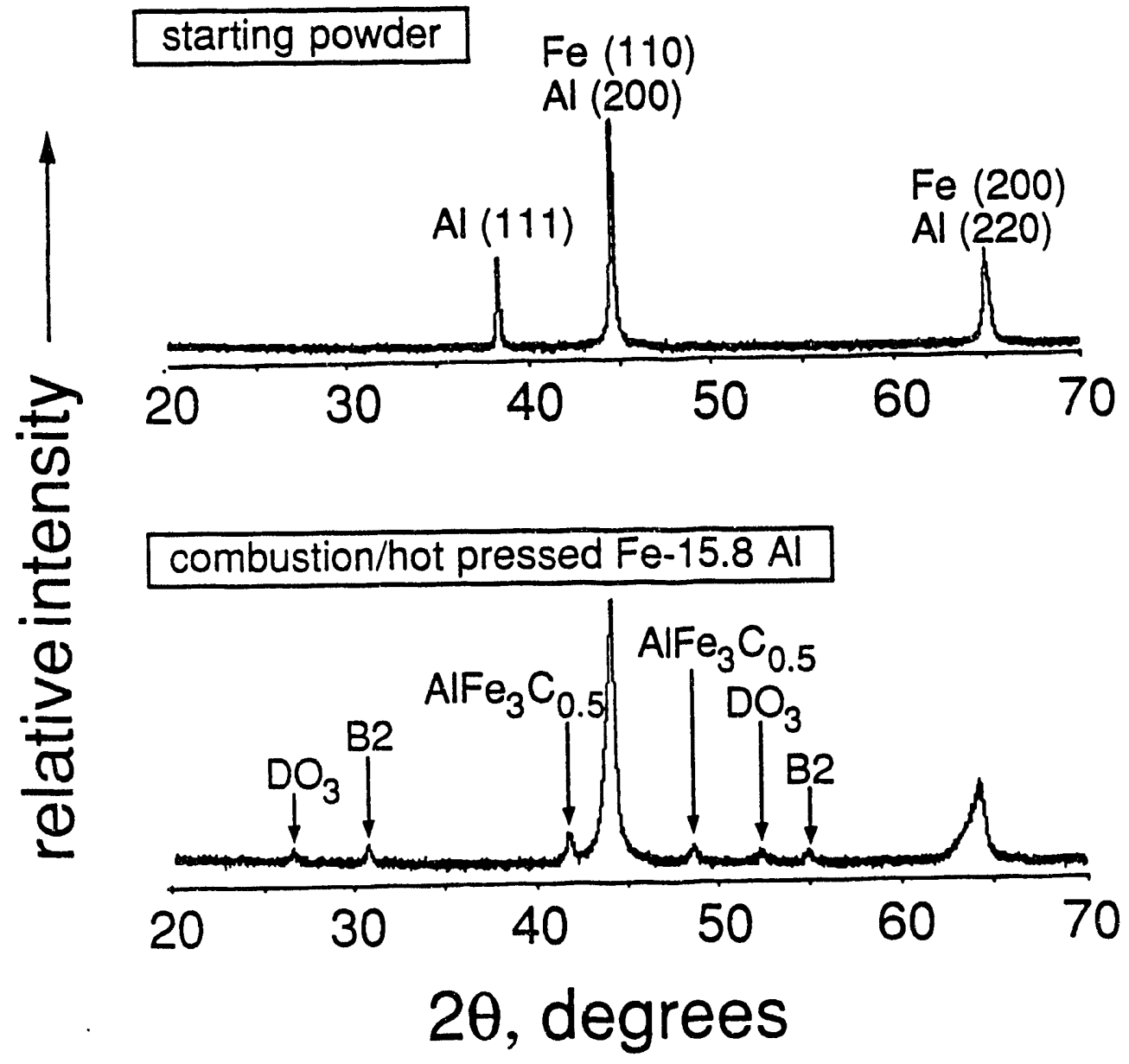

Figure 10. X-ray diffraction patterns for (a) the starting elemental powders and (b) the reaction product after hot pressing. 


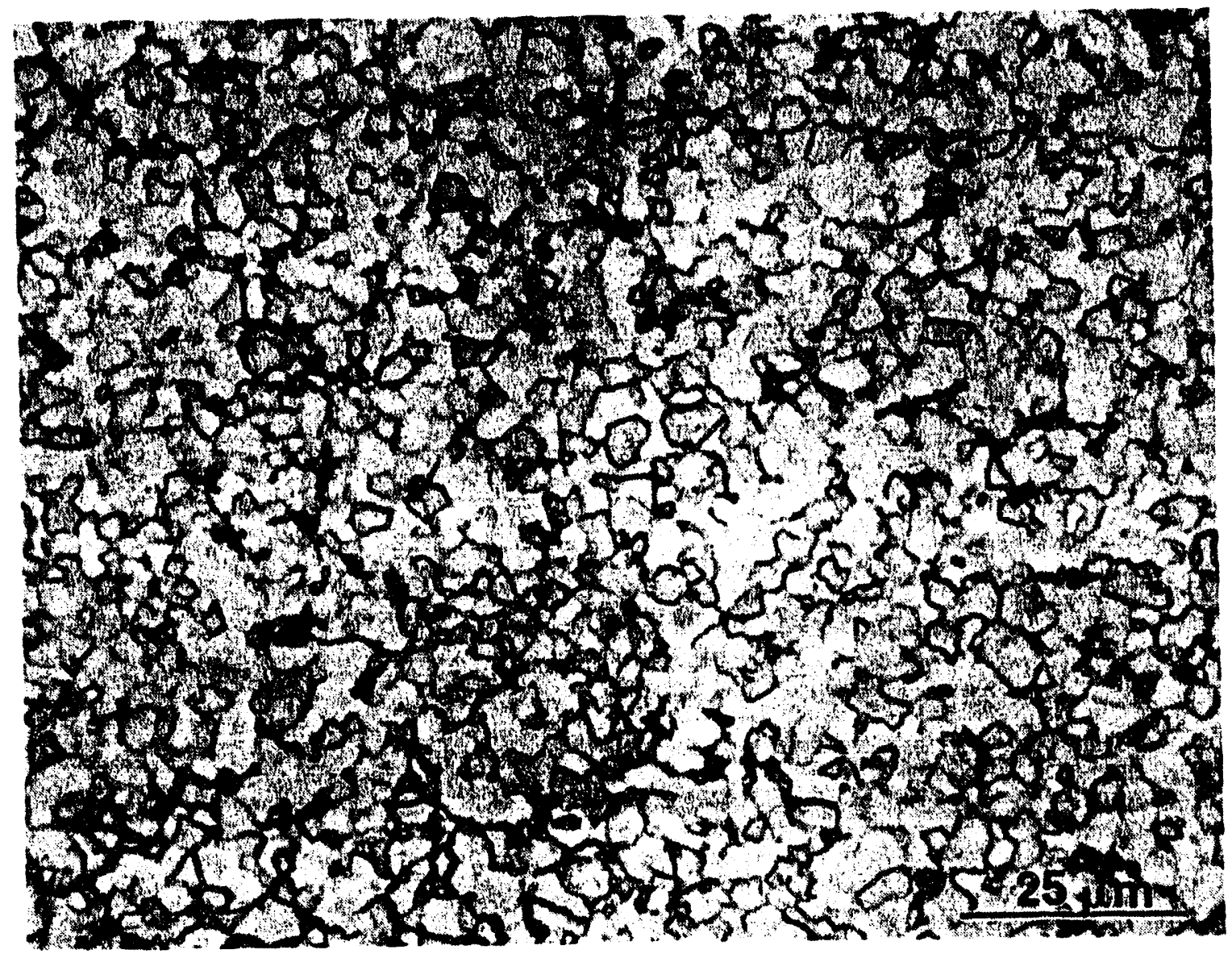

Figure 11. Optical micrograph of HIPped binary $\mathrm{Fe}_{3} \mathrm{Al}$ with $3 \mu \mathrm{m}$ diameter aluminum powder in polished and etched condition. 
The microstructures of hot pressed, HIPped and Ceracon consolidated materials were similar. The Ceracon process is somewhat more flexible for the alloys that contain $\mathrm{Cr}$; pressureless reaction sintering and homogenization can be carried out and consolidation can be performed as a separate step without canning the preform.

\section{Resistance to Grain Growth}

The fine grain size that is produced by reaction synthesis is very stable at high temperature. Figure 12 shows the grain size as a function of isothermal annealing time for combustion synthesized, powder metallurgy and ingot metallurgy $\mathrm{Fe}_{3} \mathrm{Al}+5 \% \mathrm{Cr}$. Note that little grain growth has occurred in the combustion synthesized material even after annealing $100 \mathrm{~h}$ at $1300^{\circ} \mathrm{C}$. A bright field electron micrograph of a solution treated alloy containing $5 \% \mathrm{Cr}$ is shown in Figure 13. There is a high density of $\mathrm{Al}_{2} \mathrm{O}_{3}$ particles, which have a bimodal size distribution. The large particles are oxides that were on the surface of the original aluminum particles. The spacing and distribution of the fine particles within the grains suggests that they were originally iron oxides associated with the iron particle surfaces and were transformed to aluminum oxide during the combustion synthesis reaction. The grain growth resistance is believed due to the unique microstructure resulting from the combustion synthesis process.

\section{Mechanical Properties}

The mechanical properties of several combustion synthesized materials are given in Table 3, along with values for hot extruded pre-alloyed powder for comparison. As noted above, the addition of 2 to $5 \% \mathrm{Cr}$ greatly increases the ductility of conventionally processed $\mathrm{Fe}_{3} \mathrm{Al}$; room temperature tensile elongation as large as $20 \%$ has been reported for warm-worked material that has been quenched from above $600^{\circ} \mathrm{C}$ to retain the $\mathrm{B} 2$ structure at room temperature. Addition of $\mathrm{Cr}$ in solution results in material that is more ductile at room temperature compared to the binary composition. It is evident that the combustion synthesized material containing $5 \% \mathrm{Cr}$ has more than twice the yield strength of the extruded pre-alloyed powder when both are heat treated to the B2 condition, but only half the elongation to failure. The most likely explanation for the increased strength is the refined grain size of the combustion synthesized material compared to the pre-alloyed powder, which has a grain size of approximately $40 \mu \mathrm{m}$. It is expected that the ductility of the combustion synthesized material could be improved further by thermomechanical processing subsequent to synthesis.

\section{Coatings}

The limited creep strength of alloys based on $\mathrm{Fe}_{3} \mathrm{Al}$ suggests that the initial application of these alloys may be as coatings to take advantage of their resistance to environmental degradation. Preliminary experiments suggest that it may be feasible to form extremely fine grained coatings on carbon steel substrates using combustion synthesis. An optical micrograph of a Fe-28\% Al coating on a low carbon steel formed by in situ reaction in a hot press is shown in Figure 14. The coating is fully dense and appears to be well bonded to the substrate. Microstructural evidence and chemical analysis using EDS indicate that carbon has diffused from the steel into the coating, and aluminum has diffused from the coating into the substrate. Further 


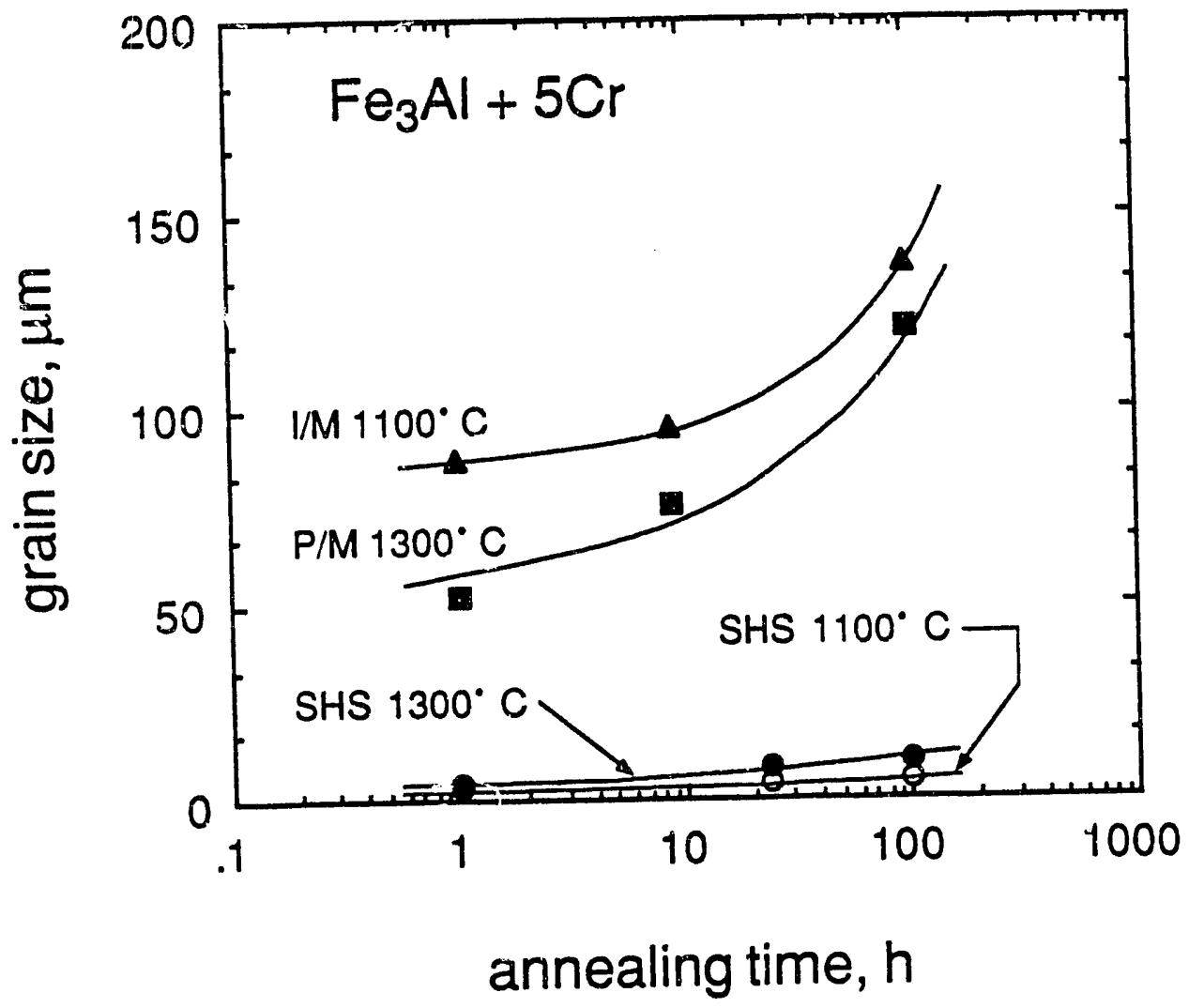

Figure 12. Grain size as a function of annealing time for combustion synthesized (SHS) $\mathrm{Fe}_{3} \mathrm{Al}+$ $5 \% \mathrm{Cr}$. Data for traditional ingot metallurgy (I/M) of the same composition is shown for comparison. 


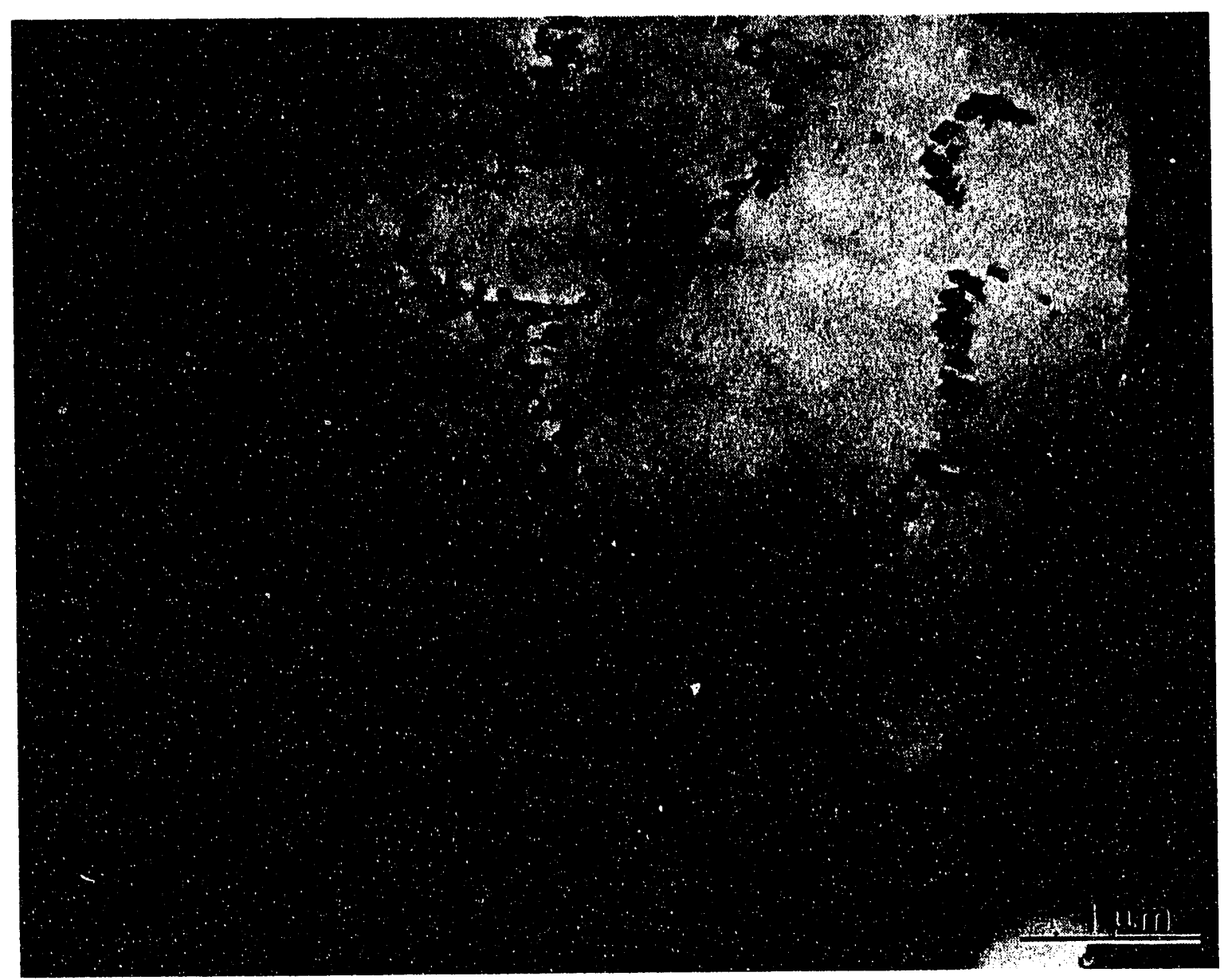

Figure 13. Bright field electron micrograph of a solution treated alloy containing $5 \% \mathrm{Cr}$ showing $\mathrm{Al}_{2} \mathrm{O}_{3}$ particles. 
Table 3. Room temperature tensile properties of $\mathrm{Fe}_{3} \mathrm{Al}$ alloyed with chromium and fabricated using self-propagating high temperature synthesis. Data for hot extruded prealloyed powder are included for comparison.

\begin{tabular}{|c|c|c|c|c|}
\hline Material & Condition & $\begin{array}{c}\text { Yield } \\
\text { strength } \\
\mathrm{MPa}\end{array}$ & $\begin{array}{c}\text { Ultimate } \\
\text { strength } \\
\mathrm{MPa}\end{array}$ & $\begin{array}{l}\text { Elongation } \\
\text { Pct }\end{array}$ \\
\hline $\mathrm{SHS} \mathrm{Fe} \mathrm{Fl}_{3} \mathrm{Al} \mathrm{2Cr}$ & $\begin{array}{l}24 \mathrm{~h} \text { at } 1100^{\circ} \mathrm{C} \text {; HIP at } \\
1100^{\circ} \mathrm{C}, 207 \mathrm{MPa}\end{array}$ & 884 & 1,101 & 5 \\
\hline $\mathrm{SHS} \mathrm{Fe}{ }_{3} \mathrm{Al}+5 \mathrm{Cr}$ & $\begin{array}{l}24 \mathrm{~h} \text { at } 1100^{\circ} \mathrm{C} \text {; HIP at } \\
1100^{\circ} \mathrm{C}, 207 \mathrm{MPa}\end{array}$ & 995 & 1,060 & 3 \\
\hline $\mathrm{SHS} \mathrm{Fe}_{3} \mathrm{Al}+5 \mathrm{Cr}$ & $\begin{array}{l}24 \mathrm{~h} \text { at } 1100^{\circ} \mathrm{C} ; \mathrm{HIP} \text { at } \\
1100^{\circ} \mathrm{C}, 207 \mathrm{MPa} ; 2 \mathrm{~h} \text { at } \\
750^{\circ} \mathrm{C} \text {; oil quench }\end{array}$ & 857 & 1,095 & 7 \\
\hline $\mathrm{P} / \mathrm{M} \mathrm{Fe} \mathrm{F}_{3} \mathrm{Al}+5 \mathrm{Cr}$ & $\begin{array}{l}1 \mathrm{~h} \text { at } 1100^{\circ} \mathrm{C} ; 2 \mathrm{~h} \text { at } \\
750^{\circ} \mathrm{C} \text {, oil quench }\end{array}$ & 358 & 726 & 11.8 \\
\hline
\end{tabular}




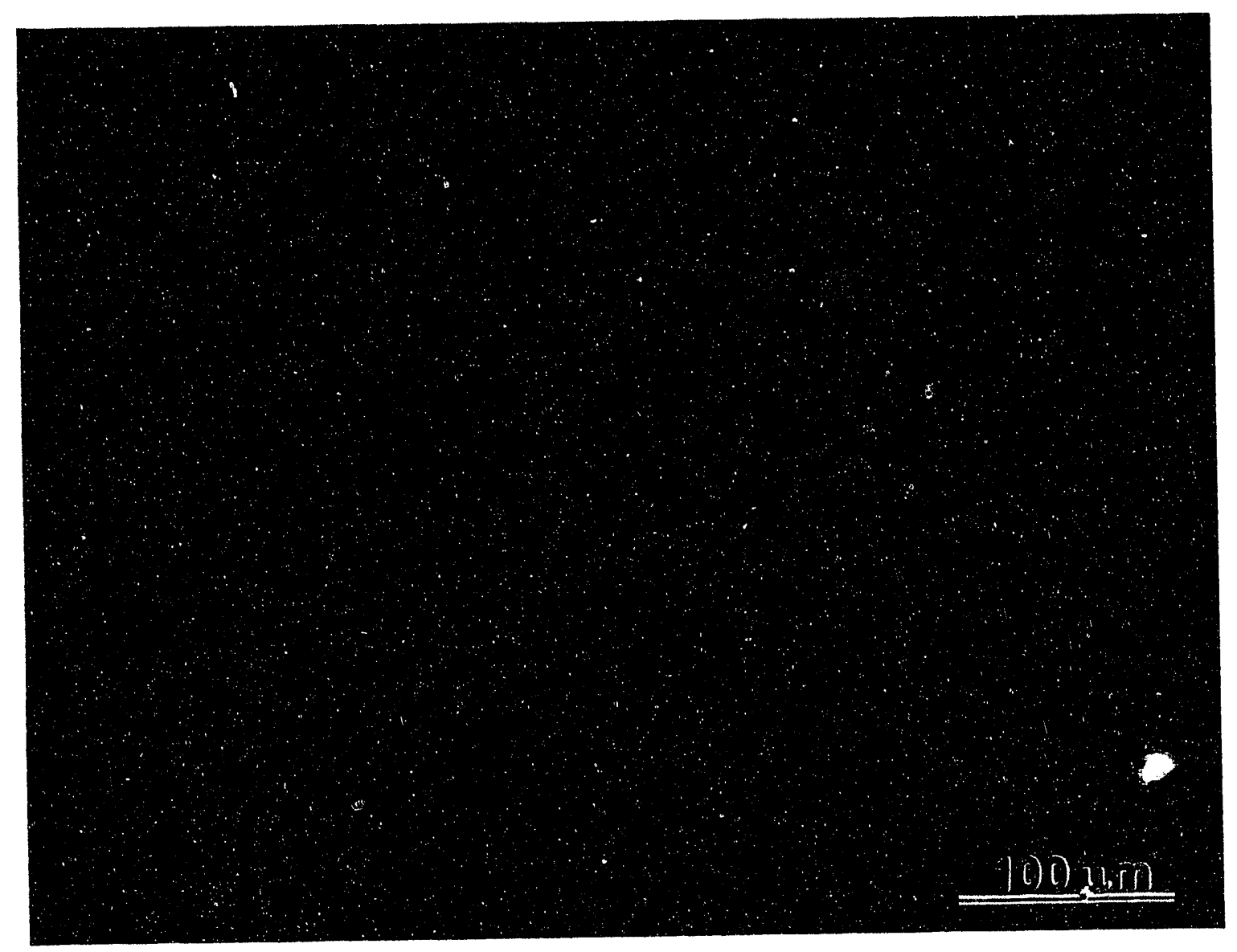

Figure 14. Optical micrograph of a combustion synthesized iron aluminide coating formed on a low carbon steel substrate in the hot press. 
development will be needed to determine if it is possible to fabricate coatings using pressureless densification.

\section{Joining}

The limited ductility of alloys that are designed to have improved elevated temperature strength has resulted in difficulty in joining using conventional fusion welding techniques. Reaction synthesis has been applied to joining other brittle materials and the low heat input suggests that it might be an attractive method for joining $\mathrm{Fe}_{3} \mathrm{Al}$. An optical micrograph of a joint formed by reacting elemental powders between extruded pre-alloyed powder monoliths under a pressure of $50 \mathrm{MPa}$ in a hot press is shown in Figure 15. It is evident from the micrograph that the reaction synthesized material has a much finer grain size than the adjacent material, and it appears to be bonded to the substrate. For both coating and joining applications, the reduction of iron oxide during reaction implies that surface concitions of the substrate materials may not be a significant problem.

\section{Wear Resistant Particle Reinforced Composites}

As noted above, the abrasive wear and cavitation erosion resistance of iron aluminide alloys fabricated by conventional ingot metallurgy have been found to rival those of several conventional wear resistant alloys. ${ }^{1}$ The fine grain size of combustion synthesized material suggested that material fabricated by this method might be superior to conventionally processed alloys. In addition to $\mathrm{Fe}-28 \% \mathrm{Al}$ and the binary with $5 \% \mathrm{Cr}$ added, $\mathrm{Fe}-28 \% \mathrm{Al}+5 \% \mathrm{Cr}$ was fabricated with 10 vol.\% $\mathrm{Al}_{2} \mathrm{O}_{3}$ as a reinforcing phase by in situ synthesis under pressure in the HIP. An optical micrograph of this material is shown in Figure 16. The particulate was dispersed during mixing of the elemental powders and is essentially inert with respect to the synthesis reaction.

The average material removal rates for a scratching-type dry abrasive wear test using $\mathrm{SiO}_{2}$ as the abrasive are presented in Table 4 for the three combustion synthesized materials, along with data for hot extruded pre-alloyed powder. It is apparent from the table that combustion synthesis results in more wear resistant monolithic material compared to pre-alloyed powder, presumably because of the refined microstructure and increased yield strength. Addition of a hard particle reinforcing phase further increases the wear resistance. The cavitation erosion rate of the combustion synthesized monolithic materials was also improved compared to the pre-alloyed powder; however, the hard particle reinforcement had little additional effect on the material loss rate. 


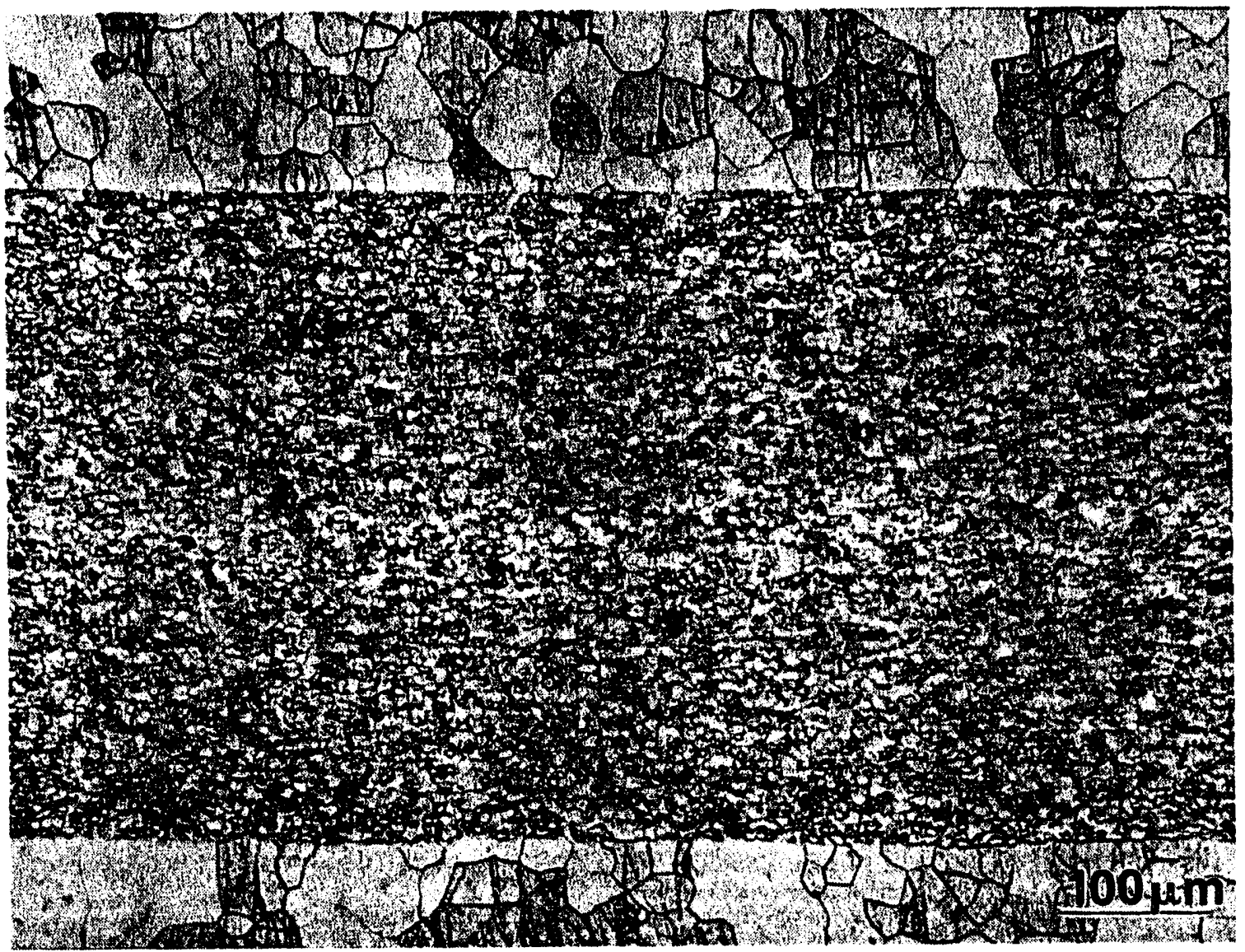

Figure 15. Optical micrograph of an SHS iron aluminide autogenous joint formed in the hot press. 


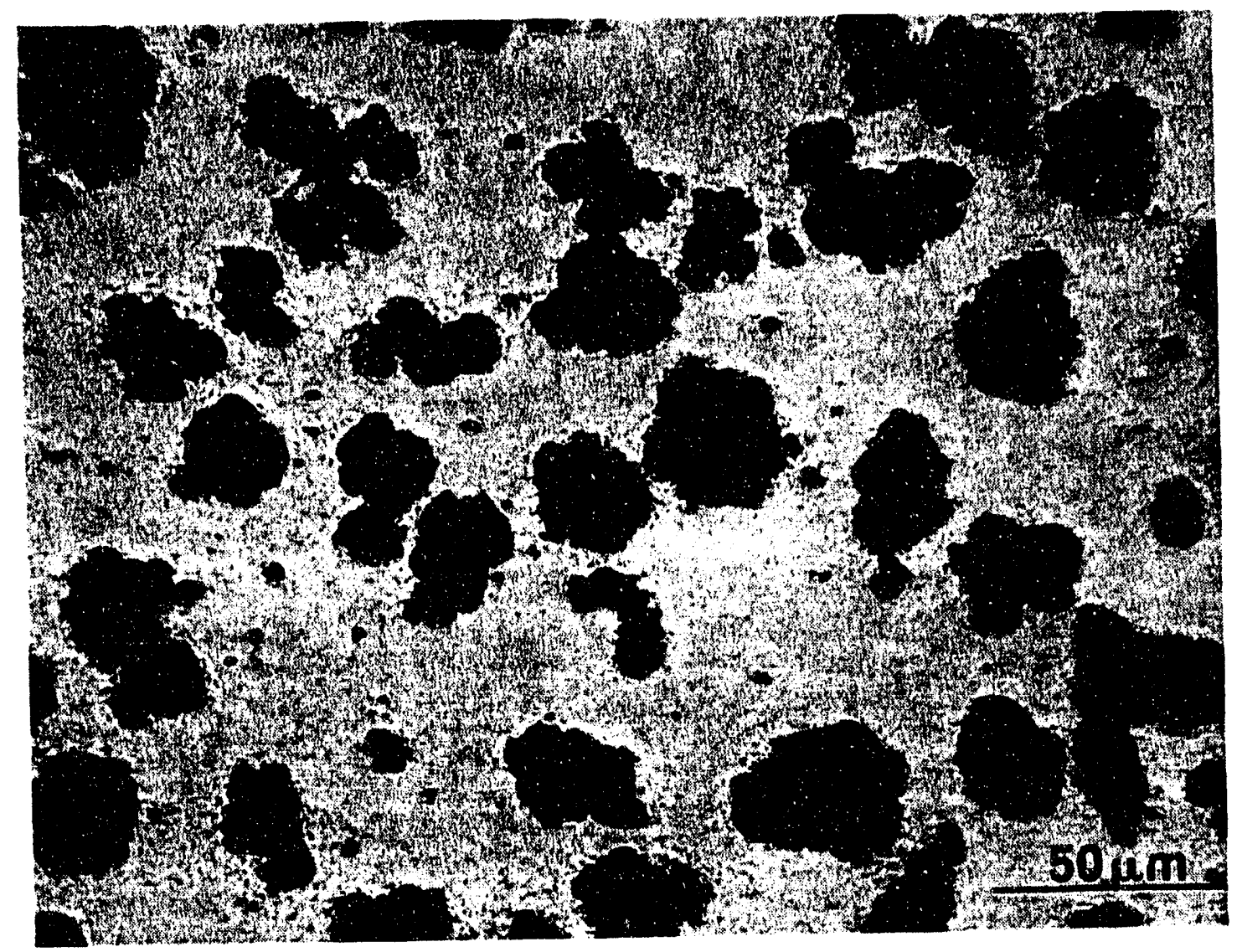

Figure 16. Optical micrograph of and $\mathrm{Al}_{2} \mathrm{O}_{3}$ particle reinforced iron aluminide composite formed by combustion synthesis in the HIP. 
Table 4. Material loss rates under abrasive wear conditions for iron aluminindes fabricated using self-propagating high temperature synthesis (SHS) and conventional power metallurgy.

\begin{tabular}{|c|c|}
\hline Material & $\begin{array}{l}\text { Wear rate, } \\
\mathrm{g} \mathrm{min}^{-1}\end{array}$ \\
\hline $\mathrm{P} / \mathrm{M} \mathrm{Fe} \mathrm{e}_{3} \mathrm{Al}+5 \mathrm{Cr}$ & 0.061 \\
\hline SHS Fe $\mathrm{Fl}_{3} \mathrm{Al}$ & 0.057 \\
\hline $\mathrm{SHS} \mathrm{Fe} \mathrm{Al}_{3}+5 \mathrm{Cr}$ & 0.050 \\
\hline SHS $\mathrm{Fe}_{3} \mathrm{Al}+5 \mathrm{Cr}+10 \mathrm{vol} \% \mathrm{Al}_{2} \mathrm{O}_{3}$ & 0.028 \\
\hline
\end{tabular}




\section{COMBUSTION SYNTHESIS OF CUBIC $\mathrm{Al}_{3} \mathrm{Ti}$}

Elemental powder mixtures were prepared having nominal stoichiometries corresponding to $\mathrm{Al}, \mathrm{Ti}, \mathrm{Al}_{73} \mathrm{Ti}_{24} \mathrm{Cr}_{3}$ and $\mathrm{Al}_{67} \mathrm{Ti}_{25} \mathrm{Cr}_{8}$. The Ti powder was -325 mesh sponge with an average particle size of 18 to $20 \mu \mathrm{m}$, and a purity of $99.5 \%$. The aluminum was $\sim 10 \mu \mathrm{m}$ spherical powder with a purity of $98.0 \%$ produced by inert gas atomization. The $\mathrm{Cr}$ powder had a 1 to $5 \mu \mathrm{m}$ particle size and also exhibited a spherical morphology. Powder mixtures were uniaxially pressed in an unlubricated steel die at a pressure of $140 \mathrm{MPa}$, giving compact densities near $70 \%$ of theoretical.

Differential thermal analysis (DTA) was conducted on $3 \mathrm{~mm}$ diameter by $1 \mathrm{~mm}$ thick compacts heated at $10^{\circ} \mathrm{C} \mathrm{min}$ mp $^{-1}$ up $1200^{\circ} \mathrm{C}$ under flowing argon. For microstructural analysis, $12.5 \mathrm{~mm}$ diameter by $\sim 6.0 \mathrm{~mm}$ thick compacts were heated under flowing argon at $20^{\circ} \mathrm{C} \mathrm{min} \mathrm{m}^{-1}$ up to maximum temperatures of 800,1200 and $1250^{\circ} \mathrm{C}$. Hold times ranged from $15 \mathrm{~min}$ to $4 \mathrm{~h}$. Combustion temperatures were measured using a $0.25 \mathrm{~mm}$ diameter wire Type $\mathrm{R}$ thermocouple inserted into the compacts.

Several densification experiments were performed. Some compacts were reacted in a graphite resistance-heated hot press under an applied pressure of $50 \mathrm{MPa}$ using BN coated graphite dies. Other specimens were encapsulated in evacuated $\mathrm{Ni}$ tubes and reacted in a HIP under an applied pressure of $100 \mathrm{MPa}$. Finally, some compacts were reacted, homogenized and then subjected to containerless hot consolidation using the Ceracon process described elsewhere. ${ }^{36}$ Transmission electron microscopy specimens were prepared from Ceracon densified materials by electropolishing in a solution of $4 \%$ perchloric acid in ethanol at $-20^{\circ} \mathrm{C}$.

\section{Results and Discussion}

The density and major phases present in compacts reacted and subjected to different thermal treatments are listed in Table 5. For all three compositions, the $\mathrm{Al}_{3} \mathrm{Ti}$ phase having the $\mathrm{DO}_{2}$ structure was the primary product of the combustion synthesis reaction, as indicated by the major peaks observed from specimens heated to $800^{\circ} \mathrm{C}$ and held for $15 \mathrm{~min}$. In the materials containing $\mathrm{Cr}$ additions there was evidence of some $\mathrm{Al}_{3} \mathrm{Ti}$ having the cubic $\mathrm{Ll}_{2}$ structure, although the quantities were small. Analysis of these products using energy dispersive spectrometry revealed a uniform distribution of $\mathrm{Al}$ and $\mathrm{Ti}$, and the existence of $\mathrm{Cr}$-rich regions at prior $\mathrm{Cr}$ particle sites, indicating incomplete dissolution of $\mathrm{Cr}$ during the reaction.

After heating to 1200 or $1250^{\circ} \mathrm{C}$ and holding for $1 \mathrm{~h}$, the alloy containing $3 \% \mathrm{Cr}$ exhibited a mixture of the $\mathrm{DO}_{22}$ and $\mathrm{Ll}_{2}$ structures. Based on relative $\mathrm{x}$-ray peak intensities, the $\mathrm{LI}_{2}$ phase accounted for approximately $40 \%$ of the structure by volume. Continued homogenization did not result in more than about $50 \%$ of the $\mathrm{L}_{2}$ phase in the $3 \% \mathrm{Cr}$ alloy. In the $8 \% \mathrm{Cr}$ alloy, the $\mathrm{L1}_{2}$ structure was the predominant phase after heating at 1200 or $1250^{\circ} \mathrm{C}$ for $1 \mathrm{~h}$. X-ray diffraction patterns for binary $\mathrm{Al}_{3} \mathrm{Ti}$ and the $8 \% \mathrm{Cr}$ material after heating at 800 and $1200^{\circ} \mathrm{C}$, respectively, for the times indicated, are shown in Figure 17. There was evidence in some $x$-ray patterns of a small amount $\left(\sim 5\right.$ vol\%) of a second phase identified as $\mathrm{Al}_{8} \mathrm{Cr}_{5}$, the highest melting point intermetallic in the Al-Cr system. A few small unidentified peaks were observed in all $\mathrm{x}$-ray patterns that were presumed to be prior particle boundary oxides. 
Table 5. Relative densities and phases present in combustion synthesized $\mathrm{Al}_{3} \mathrm{Ti}$ specimens.

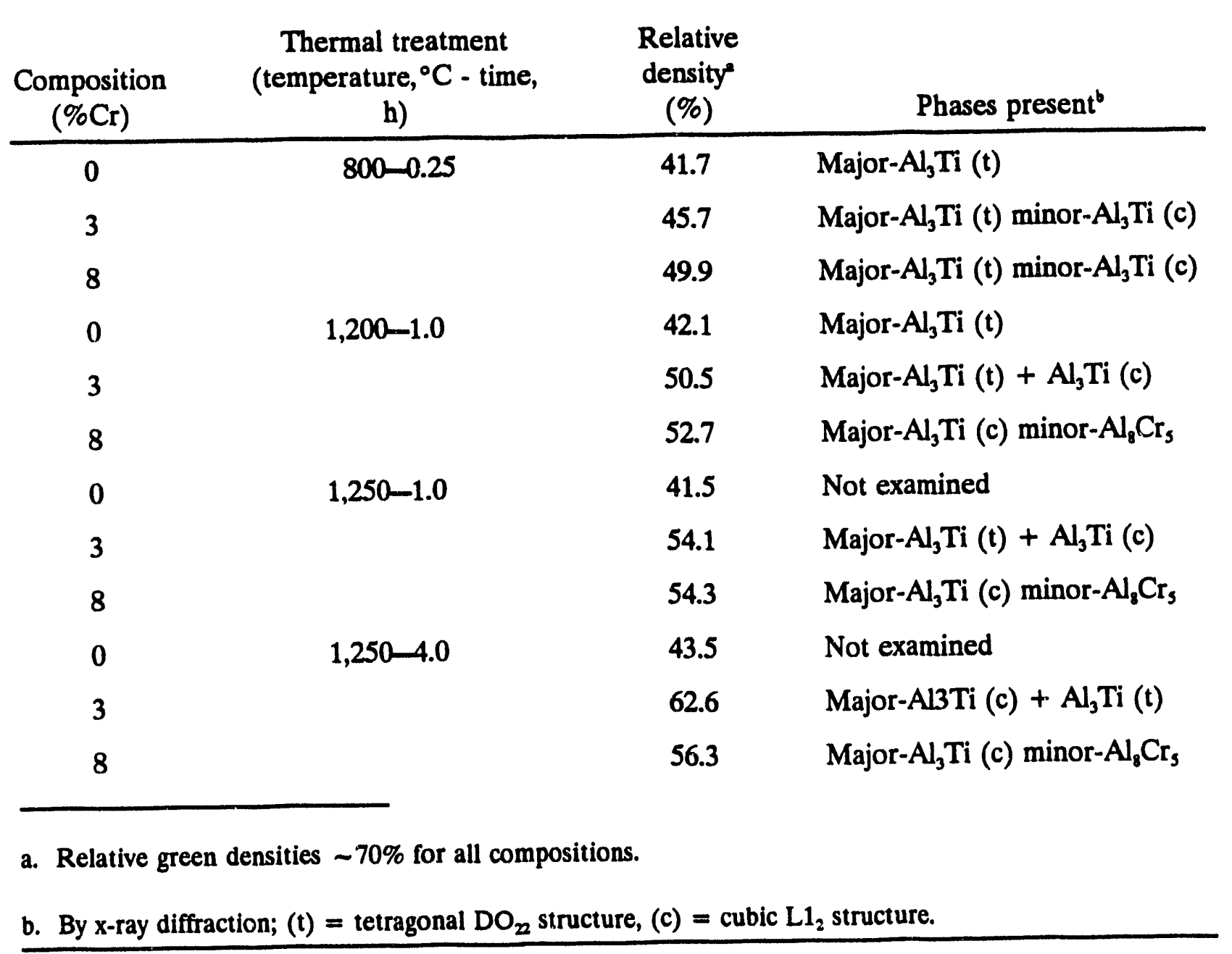




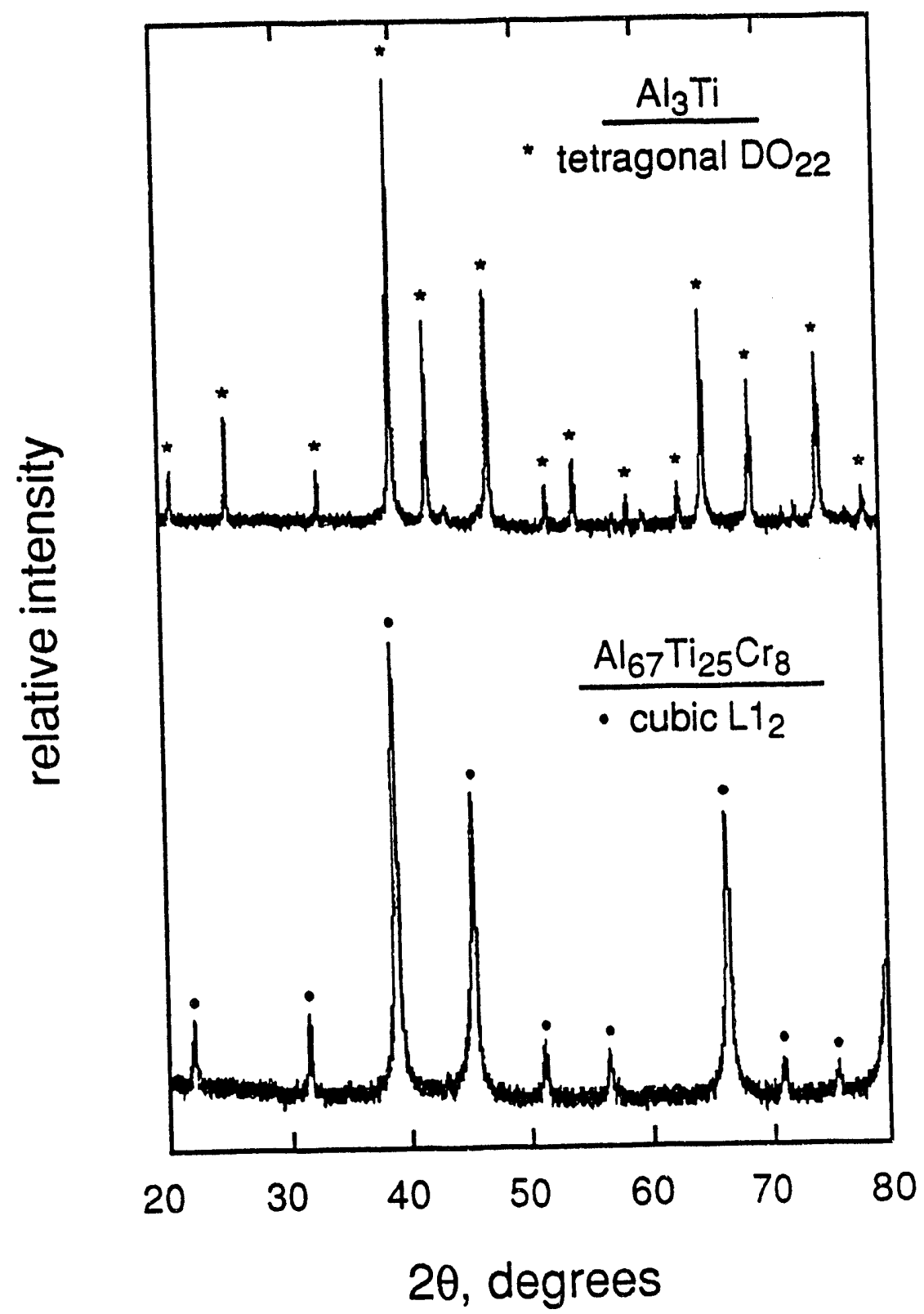

Figure 17. $\mathrm{X}$-ray diffraction patterns for binary $\mathrm{Al}_{3} \mathrm{Ti}$ and the $8 \% \mathrm{Cr}$ containing material after heat treatment at $1200^{\circ} \mathrm{C}$. 
DTA traces are shown in Figure 18 for the $\mathrm{Al}_{3} \mathrm{Ti}, \mathrm{Al}_{73} \mathrm{Ti}_{24} \mathrm{Cr}_{3}$ and $\mathrm{Al}_{67} \mathrm{Ti}_{25} \mathrm{Cr}_{2}$ compositions. For the binary composition, there is a an endotherm near $665^{\circ} \mathrm{C}$ corresponding to the peritectic reaction followed by a large exothermic peak that, according to $x$-ray diffraction, corresponds with the formation of $\mathrm{Al}_{3} \mathrm{Ti}$. Addition of chromium results in more complex DTA traces that were found to be highly reproducible. The material containing $3 \% \mathrm{Cr}$ shows a small exothermic reaction near $610^{\circ} \mathrm{C}$, the peritectic endotherm at $-665^{\circ} \mathrm{C}$, and a large exothermic peak near $670^{\circ} \mathrm{C}$. In the material containing $8 \% \mathrm{Cr}$, there were four distinct exothermic peaks between 610 and $750^{\circ} \mathrm{C}$. The endotherm corresponding to peritectic liquid formation was obscured by the exothermic peaks.

As indicated by DTA, $\mathrm{Cr}$ additions to $\mathrm{Al}_{3} \mathrm{Ti}$ compacts alter the mechanism of combustion synthesis. In order to better understand this effect, additional DTA experiments were conducted on binary mixtures of $\mathrm{Al}-\mathrm{Cr}$ and $\mathrm{Ti}-\mathrm{Cr}$ mixed in the same ratios that were present in the $\mathrm{Al}_{67} \mathrm{Ti}_{25} \mathrm{Cr}_{3}$ compacts. The $\mathrm{Ti}-\mathrm{Cr}$ exhibited no exothermic reaction on heating to $1200^{\circ} \mathrm{C}$. The $\mathrm{Al}-\mathrm{Cr}$ compact exhibited a strong reaction between 610 and $620^{\circ} \mathrm{C}$, corresponding to the first exothermic peak observed in the $\mathrm{Al}_{67} \mathrm{Ti}_{25} \mathrm{Cr}_{8}$ compacts. In agreement with the finding of a small amount of $\mathrm{Al}_{8} \mathrm{Cr}_{3}$ in the reacted materials, this result suggests that the formation of $\mathrm{Al}-\mathrm{Cr}$ intermediate products was responsible for the changes observed in Figure 18. $\mathrm{Cr}$ appears to affect mainly the ignition temperature and the earliest stages of reaction. Thus, most of the $\mathrm{Cr}$ remained undissolved after the combustion reaction, and the primary reaction product for both the binary and $\mathrm{Cr}$-containing compacts was $\mathrm{Al}_{3} \mathrm{Ti}$ having the $\mathrm{DO}_{2}$ structure. In ternary materials it is presumed that $\mathrm{Al}_{3} \mathrm{Ti}$ still forms as in the binary compacts, i.e. the reaction is preceded by peritectic liquid formation. In contrast to the binary system, however, it is notable that the $\mathrm{Al}-\mathrm{Cr}$ reactions were initiated in the solid state below $660^{\circ} \mathrm{C}$, the lowest peritectic temperature in the $\mathrm{Al}-\mathrm{Cr}$ system. Further studies are required to understand the details of the complex reaction sequence in the ternary alloys.

Using thermocouples embedded in the powder compacts, temperature histories were recorded during the reaction. There was typically a thermal arrest prior to the exothermic reaction. Peak reaction temperatures were determined to be $1240^{\circ} \mathrm{C}$ and $1160^{\circ} \mathrm{C}$ for the binary and the $8 \% \mathrm{Cr}$-containing materials, respectively, with an estimated error of $\pm 20^{\circ} \mathrm{C}$. A simplified thermodynamic analysis of the combustion temperature, described previously, ${ }^{37}$ estimated the heat of formation of the compound at $298 \mathrm{~K}$, to be $-35.0 \mathrm{~kJ} \mathrm{~mol}^{-1}$, in reasonable agreement with the value of $-36.6 \mathrm{~kJ} \mathrm{~mol}^{-1}$ determined by Kubaschewski and Dench using calorimetric methods. ${ }^{26}$ In the ternary alloys, most of the $\mathrm{Cr}$ remained undissolved, thus acting as a diluent and resulting in slightly lower combustion temperatures.

It is clear from the density values listed in Table 5 that all of the compositions exhibited swelling upon reaction. This behavior was expected based upon phase diagram characteristics of a unipolar solubility ratio i.e., appreciable solubility of $\mathrm{Al}$ in $\mathrm{Ti}$, compared to essentially no solubility of $\mathrm{Ti}$ in $\mathrm{Al}$, and large melting point difference. Cr-containing alloys appear to exhibit slightly less swelling as evidenced by higher relative densities. In addition, densities were increased slightly after heating at higher temperatures and longer times, indicating the sequential nature of the swelling and sintering events frequentiy observed in systems that exhibit these phase diagram features. ${ }^{38}$ 


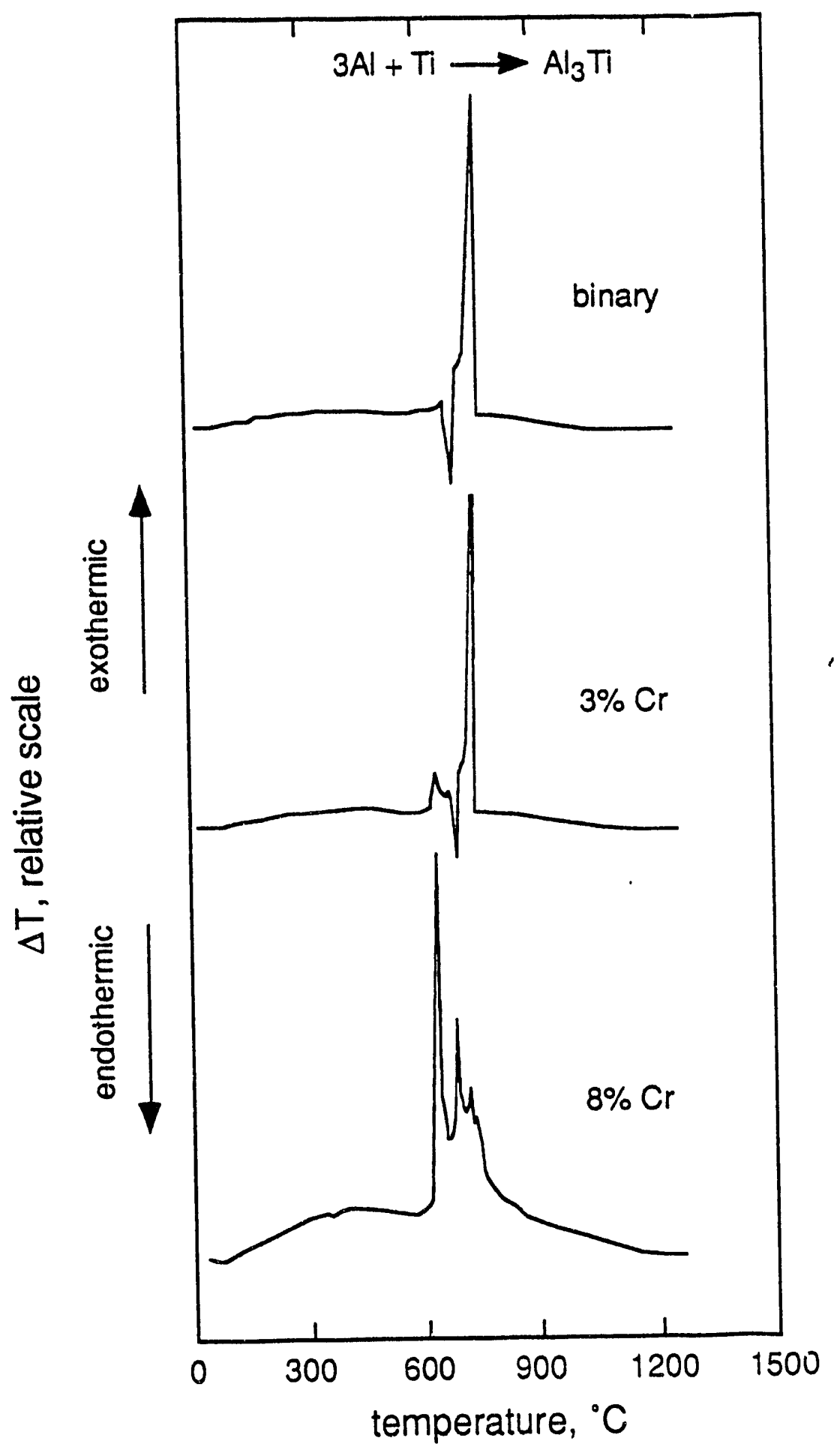

Figure 18. DTA traces obtained from $\mathrm{Al}_{3} \mathrm{Ti}, \mathrm{Al}_{73} \mathrm{Ti}_{24} \mathrm{Cr}_{8}$, and $\mathrm{Al}_{67} \mathrm{Ti}_{25} \mathrm{Cr}_{8}$. Note the appearance of the solid state exothermic reaction and the decrease in initiation temperature with increasing $\mathrm{Cr}$ content. 
Several approaches for obtaining dense alloys were investigated. Hot pressing and HIP were effective in producing near theoretical density alloys by applying external pressure during the exothermic reaction. Binary $\mathrm{Al}_{3} \mathrm{Ti}$ reacted under $50 \mathrm{MPa}$ in a hot press exhibited the $\mathrm{DO}_{2}$ structure and had a density approximately $90 \%$ of theoretical. Most of the porosity was large and spherical, indicating that entrapped gases may have prohibited complete densification. In another experiment, powders of the $\mathrm{Al}_{67} \mathrm{Ti}_{25} \mathrm{Cr}_{8}$ composition were reacted under a pressure of $100 \mathrm{MPa}$ in a HIP, and subsequently held at $1100^{\circ} \mathrm{C}$ for $1 \mathrm{~h}$. The as-HIPped material exhibited $<5 \%$ porosity, a mixture of the $\mathrm{DO}_{22}$ and $\mathrm{LL}_{2}$ phases, and undissolved $\mathrm{Cr}$ particles. This material was subsequently heat treated for $4 \mathrm{~h}$ at $1200^{\circ} \mathrm{C}$ to yield a homogeneous microstructure consisting entirely of the cubic $\mathrm{L1}_{2}$ phase. During homogenization, however, Kirkendall porosity was formed at the prior $\mathrm{Cr}$ particle sites. In order to obtain near theoretical density, this material was later hot consolidated at $1240 \mathrm{MPa}$ and $1100^{\circ} \mathrm{C}$ using the Ceracon process. ${ }^{36}$ The resulting microstructure is shown in Figure 19 ( $a$ and $b$ ). In the as-polished condition, only a small amount of residual porosity was evident, on the order of $1 \%$. In addition, a large number of small, dark particles were visible along prior particle boundaries; these are presumed to be oxides that were originally present on the powder particle surfaces. Considerable difficulty was encountered while attempting to reveal the grain structure. A wide variety of etchants was tried and it was found that the material was very resistant to uniform etching; severe pitting of grain boundaries was frequently observed. The optical micrograph in Figure $19 \mathrm{~b}$ shows an example of the best results, in which etching has revealed different grain orientations. An equiaxed microstructure is apparent and the grain size was on the order of $50 \mu \mathrm{m}$. Additional apparent porosity was formed during etching due to removal of particles along grain boundaries.

Transmission electron micrographs of the densified $\mathrm{Al}_{67} \mathrm{Ti}_{25} \mathrm{Cr}_{8}$ material are shown in Figure 20 and Figure 21. Figure 20 is a low magnification view showing the subgrain structure. Note that there are few dislocations inside the grains, and that there are a large number of particles decorating grain boundaries. Positive identification of the particles has not yet been obtained; however, based on energy dispersive $x$-ray data indicating the particles are nearly pure $\mathrm{Al}$, they are presumed to be $\mathrm{Al}_{2} \mathrm{O}_{3}$. Figure 21 shows a high magnification view of the microstructure and reveals the presence of a large number of lath precipitates aligned along the $\{100\}$ planes of the matrix. The selected area diffraction pattern for these precipitates matches that identified by Kumar et al..$^{30}$ as $\mathrm{Al}_{2} \mathrm{Ti}$.

Transverse rupture bars were prepared from the densified $\mathrm{Al}_{67} \mathrm{Ti}_{25} \mathrm{Cr}_{8}$ material and tested in four-point bending at room temperature. The material exhibited brittle behavior with no evidence of ductility. The fracture surface indicates transgranular cleavage was the failure mode, in agreement with observations by other investigators. ${ }^{00}$ The highest bending strength achieved was $501 \mathrm{MPa}$. This value is in good agreement with previously reported results for trialuminides, and is comparable to the best reported results for $\mathrm{Cr}$-containing alloys..$^{39,40}$ 

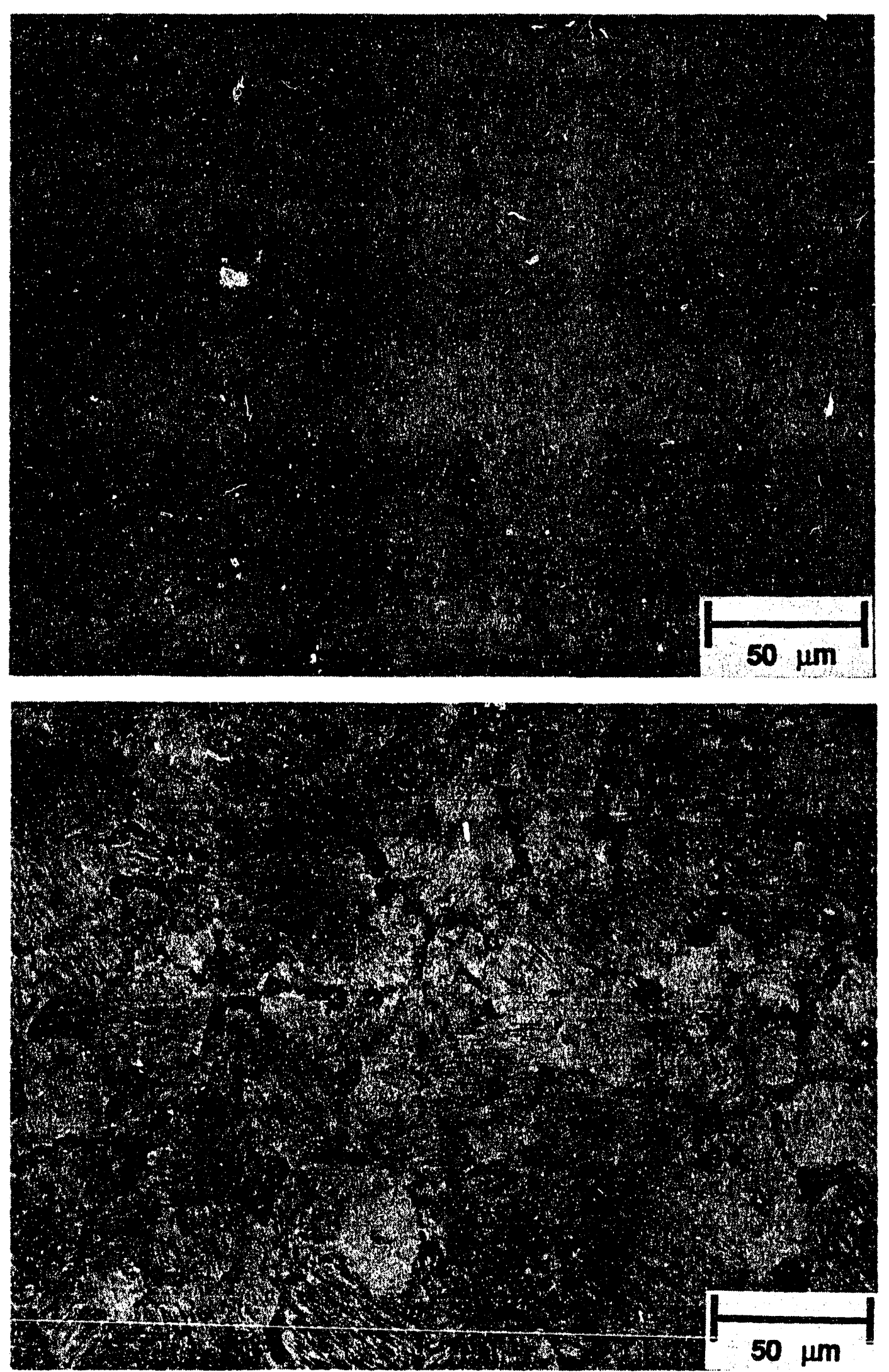

Figure 19. Optical micrographs of an $\mathrm{Al}_{67} \mathrm{Ti}_{25} \mathrm{Cr}_{8}$ sample $\mathrm{HIPped}$ at $1100^{\circ} \mathrm{C}$ for $1 \mathrm{~h}$ at $100 \mathrm{MPa}$, homogenized at $1200^{\circ} \mathrm{C}$ for $4 \mathrm{~h}$, then densified by Ceracon consolidation at $1100^{\circ} \mathrm{C}$ and $1240 \mathrm{MPa}$. Microstructures shown in the as-polished (a), and etched (b) conditions. 


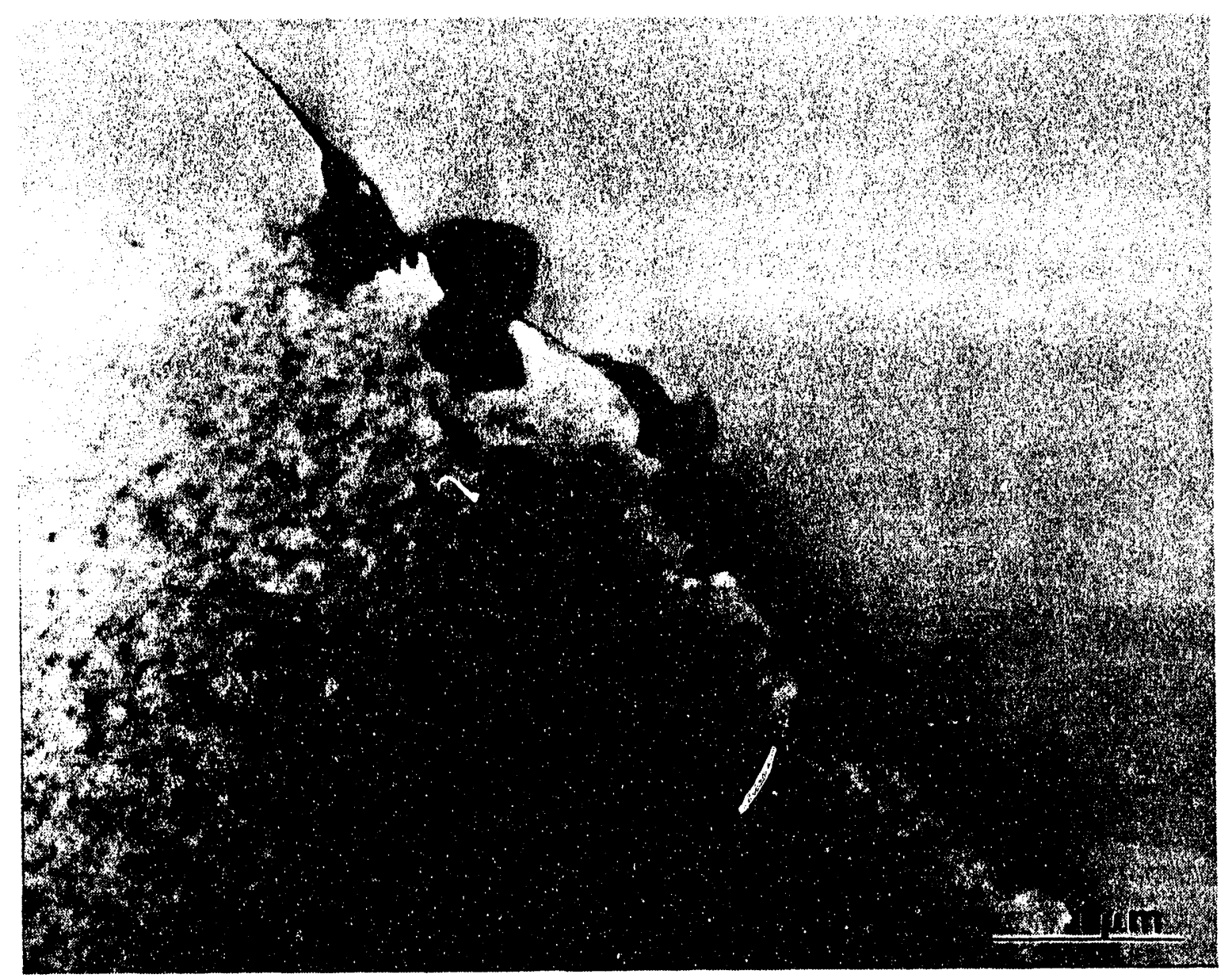

Figure 20. Transmission electron micrograph of $\mathrm{Al}_{67} \mathrm{Ti}_{25} \mathrm{Cr}_{8}$ showing low magnification view of aluminum oxide particles on a grain boundary. 
Figure 21. Transmission electron micrograph of $\mathrm{Al}_{67} \mathrm{Ti}_{25} \mathrm{Cr}_{8}$ showing high magnification view of lath shaped $\mathrm{Al}_{2} \mathrm{Ti}$ precipitates. 


\section{CONCLUSIONS}

Alloys based on $\mathrm{Fe}_{3} \mathrm{Al}$ exhibit excellent resistance to abrasive wear and cavitation erosion. Increasing the alloy content to raise the critical temperature for the $\mathrm{DO}_{3}$ to $\mathrm{B} 2$ transformation significantly increases the resistance to both wear and erosion. Considerable disordering occurs as a result of extensive plastic deformation prior to material removal in both wear and erosion.

Fully dense $\mathrm{Fe}_{3} \mathrm{Al}$ has been produced by reaction synthesis from elemental powders under applied pressure using hot pressing, hot isostatic pressing or the Ceracon process during in situ reaction or subsequent to compound formation. The reaction proceeds by outward spreading of a transient liquid phase from the initial aluminum particle sites and precipitation of the compound phase from the liquid. Combustion synthesized material has a very fine grain size that is resistant to coarsening at high temperature because of a high density of oxides from the prior particle boundaries. The fine grain size results in approximately twice the yield strength in the reaction synthesized material compared to hot extruded pre-alloyed powder. Combustion synthesis has also been successfully applied to joining $\mathrm{Fe}_{3} \mathrm{Al}$ and to forming coatings on carbon steel substrates.

Combustion synthesis has been shown to be a viable method for fabricating cubic trialuminide materials from elemental powder compacts. In the present work, nominal compositions of $\mathrm{Al}_{3} \mathrm{Ti}, \mathrm{Al}_{73} \mathrm{Ti}_{24} \mathrm{Cr}_{3}$ and $\mathrm{Al}_{67} \mathrm{Ti}_{25} \mathrm{Cr}_{8}$ were studied. In all cases, the tetragonal $\mathrm{DO}_{22}$ structure was the primary reaction product. Most of the $\mathrm{Cr}$ remained undissolved after reaction, and a homogenization heat treatment at $1200^{\circ} \mathrm{C}$ or above was used to produce the $\mathrm{L}_{2}$ structure. Additions of $\mathrm{Cr}$ also influenced the ignition temperature and reaction sequence as a result of solid state $\mathrm{Al}-\mathrm{Cr}$ interactions during heating. Fully dense, homogeneous materials exhibiting an equiaxed grain structure were produced by conducting the reaction and homogenization under external pressure, or by conducting the reaction and homogenization in a furnace and subsequently densifying the porous preform by hot consolidation. The microstructures and properties of the combustion synthesized cubic $\mathrm{Al}_{67} \mathrm{Ti}_{25} \mathrm{Cr}_{8}$ were similar to those reported for other fabrication methods. 


\section{REFERENCES}

1. R. N. Wright and D. E. Mikkola, Materials Science and Engineering, 26, 1976, pp. 263-268.

2. M. Johnson, D. E. Mikkola, P. A. March and R. N. Wright, Wear, 140, 1990, pp. 279-287.

3. C. G. McKamey, J. A. Horton and C. T. Liu, Scripta Metallurgica, 22, 1988, pp. 1679-1681.

4. C. G. McKamey, J. A. Horton and C. T. Liu, Joumal of Materials Research, 4, 1989, pp. 1156-1163.

5. V. K. Sikka, U. S. DOE Fossil Energy Materials Conference Proceedings, Oak Ridge, TN, 1991 , in press.

6. J. R. Knibloe, R. N. Wright and V. K. Sikka, Advances in Powder Metallurgy, 2, 1990, pp. 219-231.

7. R. S. Diehm, M. P. Kemppainen and D. E. Mikkola, Materials and Manufacturing Processes, 4, 1989, pp. 61-72.

8. C. T. Liu, C. G. McKamey and E. H. Lee, Scripta Metallurgica, 24, 1990, pp. 385-390.

9. D. B. Kasul and L. A. Heldt, Scripta Metallurgica, 25, 1991, pp. 1047-1051.

10. B. H. Rabin and R. N. Wright, Metallungical Transactions, 22A, 1991, pp. 277-286.

11. B. H. Rabin and R. N. Wright, Metallurgical Transactions, 23A, 1992, pp. 35-40.

12. A. Bose, B. H. Rabin and R. M. German, Powder Metallurgy International, 20, 1988, pp. 25-34.

13. W. R. Wrzesinski and J. C. Rawers, Journal of Materials Science Letters, 9, 1990, pp. 432-434.

14. M. Dahms, J. Seeger, W. Smarsly and B. Wildhagen, Iron and Steel Institute Japan International, 31, 1991, pp. 1093-1099.

15. D. M. Bowden, U. S. Patent 5,015,440, 1991.

16. H. Mabuchi, K. Hirukawa, K. Katayama and Y. Nakayama, Scripta Metallurgica, 24, 1990, 1553-1557.

17. H. Mabuchi, K. Hirukawa, H. Tsuda and Y. Nakayama, Scripta Metallurgica, 24, 1990, pp. 505-511.

18. R. Lerf and D. G. Móorris, Acta Mítaliurgica, 39, 1991, pp. 2419-2429. 
19. S. Zhang, J. P. Nic and D. E. Mikkola, Scripta Metallurgica, 24, 1990, pp. 57-61.

20. A. Raman and K. Schubert, Metallkunde, 56, 1965, pp. 55-67.

21. S. Zhang, J. P. Nic, W. W. Milligan and D. E. Mikkola, Scripta Metallurgica, 24, 1990, pp. 1441-1447.

22. M. Yamaguchi, Y. Umakoshi and T. Yamane, Philosophical Magazine, 55, 1987, pp. 301-309.

23. J. Tarnaci and Y.-W. Kim, Scripta Metallurgica, 22, 1988, pp. 329-335.

24. S. A. Brown, K. S. Kumar and J. D. Wittenberger, Scripta Metallurgica, 24, 1990, pp. 2001-2007.

25. K. S. Kumar and J. R. Pickens, Scripta Metallurgica, 22, 1988, pp. 1015-1021.

26. O. Kubaschewski and W. A. Dench, Acta Metallurgica, 3, 1955, pp. 339-347.

27. ASTM Standard G 32-85, 1985.

28. P. A. March, Tennessee Valley Authority Report WR28-4-900-213, 1988.

29. P. A. March, Proceedings of the Cavitation and Multiphase Flow Forum, American Society for Mechanical Engineers, New York, 1987, pp. 72-76.

30. ASTM Standard G 65-80, 1980.

31. ASTM Standard B 611-76, 1976.

32. N. S. Stoloff and R. G. Davies, Progress in Materials Science, 13, 1964, pp. 1-65.

33. R. T. Fortnum and D. E. Mikkola, Materials Science and Engineering, 91, 1987, pp. 223-230.

34. R. S. Diehm and D. E. Mikkola, High Temperature Ordered Intermetallic Alloys II, Materials Research Society, 81, N. S. Stoloff, C. C. Koch, C. T. Liu and O. Izumi, eds., Materials Research Society, Pittsburgh, PA, 1987, pp. 329-334.

35. J. S. Sheasby, International Joumal of Powder Metallurgy Technology, 15, 1979, pp. 301-305.

36. B. H. Rabin, R. N. Wright, J. R. Knibloe, R. V. Raman and S. V. Rale, Materials Science and Engineering, 153, 1992, pp. 706-711.

37. R. N. Wright, B. H. Rabin and W. H. McFerran, Journal of Materials Research, 1992, in press.

38. R. M. German and B. H. Rabin, Powder Metallurgy, 28, 1985, pp. 7-15. 
39. K. S. Kumar, M. S. DiPietro, S. A. Brown and J. D. Whittenberger, NASA Technical Memorandum 105628, NASA Lewis Research Center, Cleveland, OH, 1992.

40. E. P. George, D. P. Pope, C. L. Fu and J. H. Schneibel, Iron and Steel Institute of Japan International, 31, 1991, pp. 1063-1070. 

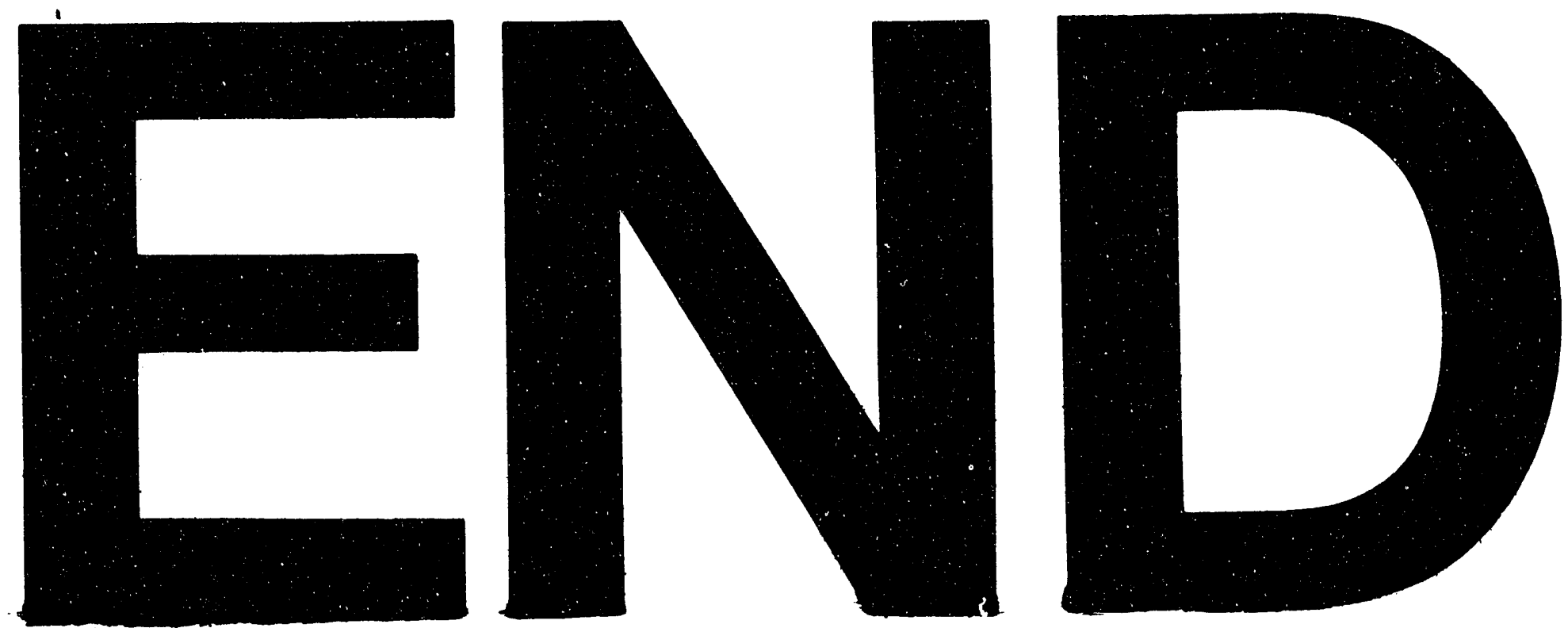

x
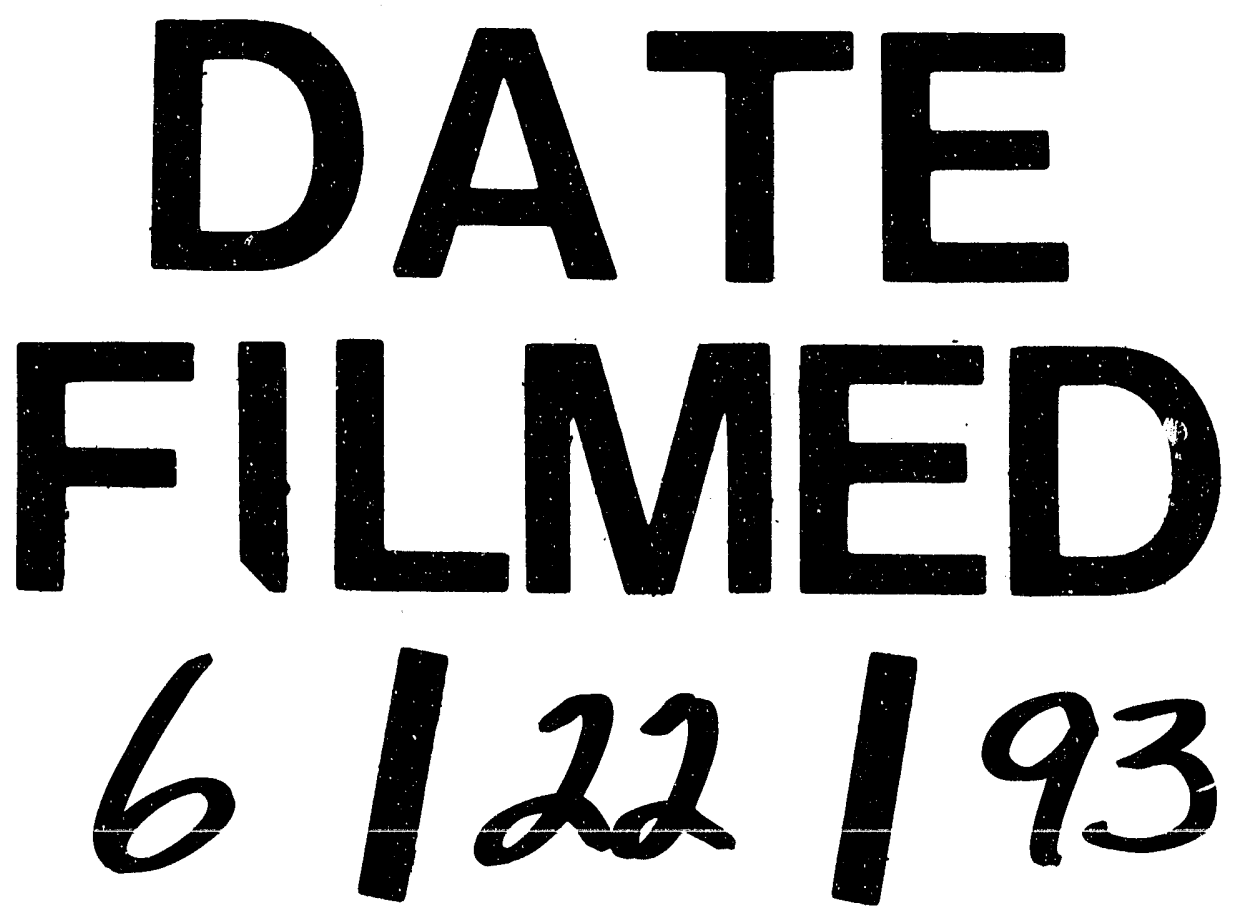
